Review

\title{
Antioxidants: Reviewing the chemistry, food applications, legislation and role as preservatives
}

\author{
Márcio Carocho $^{\mathrm{a}}$, Patricia Morales ${ }^{\mathrm{b}}$, Isabel C.F.R. Ferreira ${ }^{\mathrm{a}, *}$ \\ ${ }^{a}$ Mountain Research Centre, (CIMO), ESA, Polytechnic Institute of Bragança, Campus de Santa Apolónia, 5300-253, Bragança, Portugal \\ b Department of Nutrition and Bromatology II, Faculty of Pharmacy, Complutense University of Madrid, Plaza Ramón y Cajal, s/n, 28040, Madrid, Spain
}

\section{A R T I C L E I N F O}

\section{Keywords:}

Food antioxidants

Free radicals

Additives

E number

\begin{abstract}
A B S T R A C T
Background: Food antioxidants play a critical role in the food industry, and have become one of the most widespread methods of conserving food. Their cheapness and ease of use have made them a part of virtually all foodstuffs. Although different, all groups of food antioxidants have a same common objective, to conserve food for the longest possible time without altering it, conferring taste or color. Consumer trends have shifted the industry to find natural antioxidants for conservation, and although synthetic additives have been the mainstream, their natural counterparts have been gaining interest.

Scope and approach: This review focuses of the different antioxidant groups, describing their properties, function and applicability, as well as indexing the relevant legislation in order to be a guide for academia and industry. Key findings and conclusions: The wide number of antioxidant additives allowed by the different countries if of synthetic origin, and consist of pure molecules. Although consumers are leaning toward natural additives, this offer is still quite limited despite the permission of rosemary extract within the European Union. There is still much work to be done in order to completely demystify the importance and safety of antioxidants as well as to harmonize legislation worldwide.
\end{abstract}

\section{Chemistry of free radicals and antioxidants}

The chemistry of free radicals and antioxidants is based on an equilibrium between both. Free radicals are reactive compounds that tend to capture electrons from stable biological molecules in order to stabilize themselves.

In pathological conditions, there is an overproduction of free radicals due to the presence of pro-oxidant compounds, and or different other risk factors like smoking, excess of physical activity, stress, among others, giving rise to the infamous oxidative stress. This process has three well defined steps; the first one, initiation, in which the radicals are formed, being the second one, propagation, where they react with other molecules, and finally in the third step, termination, when they transform into other products (Fig. 1). In terms of radical species, there are three major classes, the reactive oxygen species (ROS), the reactive nitrogen species (RNS) and the reactive sulfur species (RSS). Oxidative stress give way to the production of highly reactive species and radicals, like superoxide $\left(\mathrm{O}_{2} \cdot{ }^{-}\right)$, hydroxyl radical $\left(\mathrm{OH} \bullet^{-}\right)$, nitrous oxide radical (NO), alkyloxy radical (RO·), and other species like hydrogen peroxide $\left(\mathrm{H}_{2} \mathrm{O}_{2}\right)$ and atomic oxygen $(\mathrm{O} \cdot)$, that can be produced both exogenously and endogenously (Ferreira, Barros, \& Abreu, 2009).
The superoxide radical $\left(\mathrm{O}_{2}{ }^{-}\right)$, which is one of the most reactive radical species, is known to scavenge electrons from the electron transport chains of the mitochondria and the cytochrome $\mathrm{P}_{450}$, but, at the same time also scavenges them from the activated phagocytes of the human immune system. Regarding the nitrogen radical species, one of the most active compounds is nitric oxide (NO), generally produced from L-arginine (present in virtually all mammal tissues) through the nitric oxide synthase enzyme. In normal concentrations, this molecule has important physiological properties, namely as a mediator for macrophages that excerpt cytotoxic activity against neoplastic cells and microorganisms; but, when nitric oxide increases concentration, it can react with the superoxide anion without the need of a catalyst, eventually forming the peroxynitrite radical $\left(\mathrm{ONOO}^{-}\right)$, which is known to be very hazardous to the human body, reacting with various types of molecules through various mechanisms. An example of sulfur reactive species is the RS radical, formed through the oxidation of an electron of a thiol group as an intermediate step for the formation of a disulphide (Ferreira et al., 2009; Fridovich, 1983; Gruhlke \& Slusarenko, 2012; Moncada \& Higgs, 1993; Pacher et al., 2007). As detailed on Fig. 2, there are many causes for the imbalance in the production of free radicals, which then remove components of lipids, DNA and proteins,

\footnotetext{
* Corresponding author

E-mail address: iferreira@ipb.pt (I.C.F.R. Ferreira).
} 


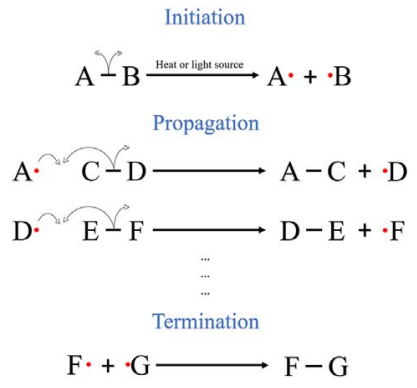

Fig. 1. The three steps of radical chain reactions, leading to oxidative stress, which is the excess production of radical species.

rendering them unstable. If not neutralized in time, free radicals can lead to diseases in many organs, namely Alzheimer, Parkinson, stroke, diabetes, Wilson's disease, rheumatoid arthritis, multiple sclerosis, lateral amyotrophic sclerosis, thalassemia, hypertension, infertility, melanin abnormalities, cataracts, asthma, allergies, heart failure, dyslipidaemia, angina and many more. To counter these diseases, the body has a set of endogenous antioxidants that act as the first line of defence, but, this battery of enzymes and other molecules are not enough, and thus, the human body relies on antioxidants from food, namely fruit, vegetables and meat as sources of these compounds (endogenous antioxidants) (Ames, Shigenaga, \& Hagen, 1993; Halliwell, 1990; Rahman, Hosen, Islam, \& Shekhar, 2012; Shah \& Channon, 2004; Valko, Rhodes, Moncol, Izakovic, \& Mazur, 2006; Yang, Guo, \& Yuan, 2008). An antioxidant can be defined as "a substance that, when present at low concentrations compared to those of an oxidizable substrate, significantly delays or prevents oxidation of that substrate" (Halliwell, 1990). This definition is universal, and can be employed to define antioxidants that fight free radicals within our bodies or when being used as food additives. All antioxidants follow one of the seven mechanisms of action, which vary with the type of oxidants: a) sequestration of free radicals from the medium; b) chelation of metallic ions; c) inhibition of free radical producing enzymes; d) activation of endogenous antioxidant enzymes; e) prevention of lipid peroxidation; f) prevention of DNA damage; g) prevention of protein modification and sugar destruction.

In terms of radical sequestration, antioxidants mainly act on $\cdot \mathrm{OH}$ and $\mathrm{O}_{2}{ }^{-}$. They either give an electron or a hydrogen atom from their hydroxyl group, thus stabilizing the radical. Some compounds with this ability are ascorbic acid, tocopherols and polyphenols.
Chelation of metals, like $\mathrm{Fe}^{2+}, \mathrm{Fe}^{3+}, \mathrm{Cu}^{2+}$ and $\mathrm{Cu}^{+}$is another mechanism of neutralization of free radicals. This mechanism is critical for the human body, given that these metals are related with the development of neurodegenerative sicknesses by reacting with $\mathrm{H}_{2} \mathrm{O}_{2}$ which is previously produced by the superoxide dismutase enzyme, leading to the production of $\cdot \mathrm{OH}$ and $\mathrm{O}_{2}{ }^{-} \cdot$. Copper and iron are oxidized to their $\mathrm{Fe}^{3+}$ and $\mathrm{Cu}^{2+}$ states, and can be quite disrupting to surrounding cells or cell parts, thus the antioxidants like quercetin and other hydroxycinnamic acids reduce them back to their stable form, allowing another oxidation process, eventually consuming all the hydrogen peroxide, leading to an inhibition of radical production through $\mathrm{H}_{2} \mathrm{O}_{2}$ (Končić, Barbari, Perković, \& Zorc, 2011; Lü, Lin, Yao, \& Chen, 2010).

Three of the most important enzymes that produce free radicals are nicotinamide adenine dinucleotide phosphate (NADPH), oxidase and xanthine oxidase. NADPH oxidase gives an electron to oxygen, forming $\mathrm{O}_{2}{ }^{-}$, while xanthine oxidase catalyzes the oxidation of hypoxanthine to xanthine, and further converting it to uric acid (which is an endogenous antioxidant), producing $\mathrm{O}_{2}{ }^{-}$. and $\mathrm{H}_{2} \mathrm{O}_{2}$ in the process. With regard to the antioxidant enzymes, two of the most important ones are superoxide dismutase and catalase, which work together to balance off the production and neutralization of free radicals. Superoxide dismutase catalyzes the dismutation of the superoxide radical into molecular oxygen and hydrogen peroxide. The hydrogen peroxide, although not being a radical poses danger to surrounding biological structures (as stated above), and thus catalase decomposes it in oxygen and hydrogen (Alfonso-Prieto, Biarnés, Vidossich, \& Rovira, 2009; Shin et al., 2009).

Lipid peroxidation is the destruction of double bonds of unsaturated lipids by ROS which can be halted by antioxidants, namely lipophilic ones like being vitamin $\mathrm{E}$, which is one of the most effective. This vitamin is actually a set of eight very similar compounds, named tocopherols and tocotrienols (four of each), which are named with the first four Greek letters, ( $\alpha$ to $\delta$ ), being $\alpha$-tocopherol the most effective against lipid peroxidation. Vitamin E works as an antioxidant on itself, but mostly forms a synergic relation with vitamin C (ascorbic acid), being regenerated successively and countering radical attack on lipids. Many sicknesses in the human body are related to lipid peroxidation, namely atherosclerosis, cancer and cardiovascular disorders. Some of the most important end products of lipid peroxidation are aldehydes, namely $\mathrm{OH} \cdot \mathrm{CCl}_{3} \mathrm{O}_{2}$ y el $\mathrm{HO}_{2}$ (Rahman, 2007).

DNA and RNA are also prone to damage by free radicals, namely NO and $\mathrm{O}_{2}{ }^{-}$, which then react with plasmid DNA, splitting the double helix and rendering oxidative damage that can translate in cancer, and

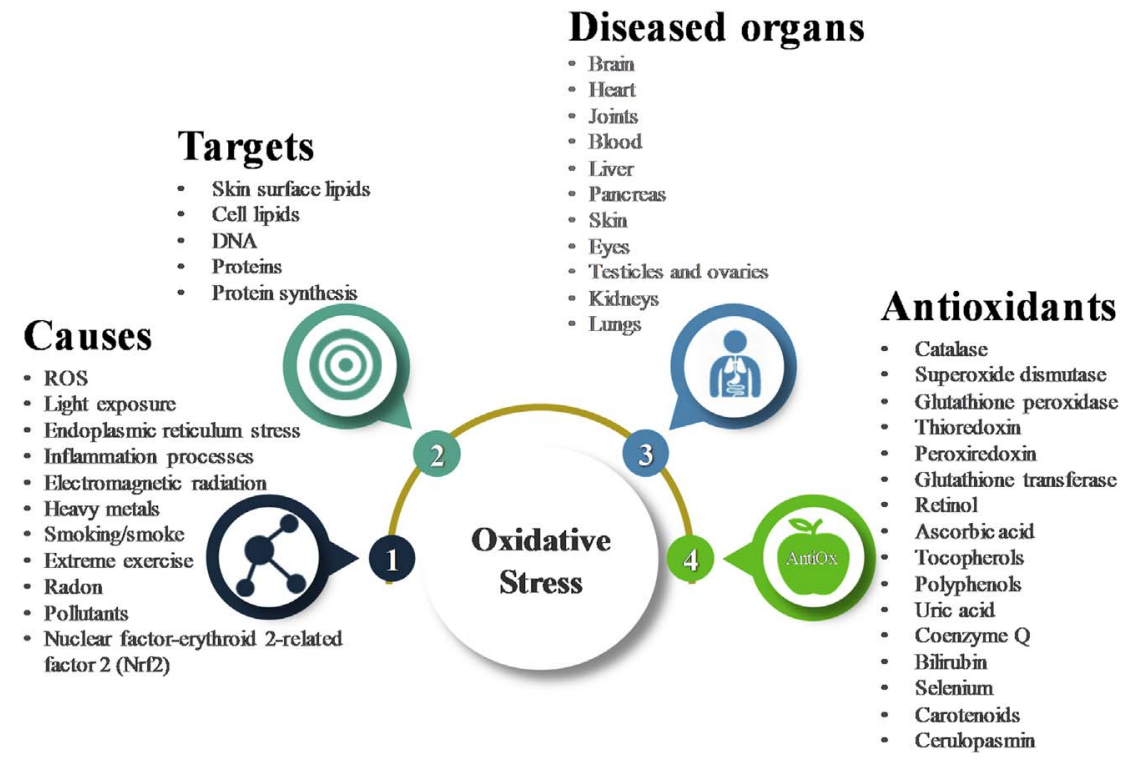

Fig. 2. Causes, targets, affected organs and antioxidants that fight oxidative stress. Adapted from Uttara, Singh, Zamboni, \& Mahajan, 2009; Avery, 2011; Birben, Sahiner, Sackesen, Erzurum, \& Kalayci, 2012; Rahman et al., 2012; Battacharyya, Chattopadhyay, Mitra, \& Crowe, 2014; Kayama et al., 2015; Pisoschi \& Pop, 2015; Yavari, Javardi, Mirmiran, \& Bahadoran, 2015; Masuda, Shimazawa, \& Hara, 2017. 
neurodegenerative diseases, but also into chromosomal abnormalities (Lobo, Phatak, \& Chandra, 2010; Valko, Izakovic, Mazur, Rhodes, \& Telser, 2004). On the other hand, aminoacids and proteins are attacked essentially by chlorination and nitration through various mechanisms, making them very sensible to destruction. They can be damaged by oxidative modifications in specific aminoacids, free radical mediated cleavage of peptides, but also by protein reticulation in lipidic peroxidation reactions (Lobo et al., 2010). ONOO-, the peroxynitrite radical is one of the strongest nitrating agents, $\mathrm{HClO}$ and ${ }^{-} \mathrm{OCl}$, hypochlorous acid and its ion are chlorination agents that attach to aminoacids and proteins (Lü et al., 2010; Zavodnik, Lapshina, Zavodnik, Soszyński, \& Bryszewska, 2002).

Finally, the probable least known target of free radicals are sugars, which are damaged during the early steps of non-enzymatic glycosylation. The fragmentation of sugars produces small chain species that can lead to the formation of $\alpha$ and $\beta$-dicarbonyls which are mutagenic compounds (Benov \& Beema, 2003).

\section{The near perfect human endogenous antioxidant system and food antioxidants}

Research in antioxidants has developed rapidly in recent years, and has reduced the demonization of free radicals and oxidative stress and their deleterious effects on the human body and health. Although it is that an excess of free radicals can lead to an unbalance in the antioxidant/free radical equilibrium, causing oxidative stress, which can lead to various types of diseases, today more and more evidence has proved that ROS are responsible for important reactions within the human body. They are attributed with important cell signalling cascades, regulation of physiological functions, inducers of cell differentiation, activation of apoptosis, stimulation of glucose transport into cells and other important task within the human body, making it an important part of the innate immune system (Mirończuk-Chodakowska, Witkowska, \& Zujko, 2018). Concomitantly, in order to counter the dangerous effects of free radicals interacting with biological cells, membranes or organs, the human body has a set of endogenous antioxidants molecules. Wu et al. (2013a) defined the three lines of action of the endogenous mechanisms, namely a preventive line - the first line of defence in preventing reactions that lead to the formation of reactive species to occur; a second repairing line, in which these molecules interrupt radical oxidation reactions; and finally, a third line with inactivators of the products of free radical reactions by repairing or elimination of the damage. The human endogenous antioxidants are grouped according to the molecular type, namely enzymatic and nonenzymatic antioxidants. The first line, is composed of both enzymatic and non-enzymatic molecules, such as superoxide dismutase which deprotonates the superoxide anion, catalase, glutathione peroxidase, peroxiredozins (enzymatic), but also ceruloplasmin, ferritin, transferrin and albumin (non-enzymatic). The second line is strictly a non-enzymatic one that rapidly inactivate reactions, including vitamins, enzyme cofactors, organosulfur compounds and nitrogen non-protein compounds. The third line, which involves repair mechanisms caused by ROS, RNS and RSS, has enzymatic antioxidants that repair damaged DNA and proteins, and further fight oxidized lipids and the propagation of peroxyl lipid radical chains in cells and membranes (Carocho \& Ferreira, 2013a; Mirończuk-Chodakowska et al., 2018; Wu, Kosten, \& Zhang, 2013a). Although extremely important and well prepared for oxidative stress, the endogenous antioxidants are not enough, and the systems is not perfect in eliminating the produced free radicals. This flawed system is aided by the consumption of antioxidants in food, quenching the excess production of free radicals in the human body, which is increasing thanks to changing lifestyles, pollution and other risky behaviours. These exogenous antioxidants can be phenolic acids, flavonoids, vitamins, carotenoids, minerals and organosulfur compounds, being the main sources of these compounds fruits and vegetables (Carocho \& Ferreira, 2013a). Thus, given the benefits of these compounds to the human antioxidant system, much research has been put forth to use these molecules as food additives, especially antioxidants, conferring their protective properties to foodstuffs, reducing the need for synthetically produced compounds. Although fruits and vegetables are packed with antioxidants that are very important as exogenous free radical quenchers, avoiding oxidative stress, their bioavailability and bioaccessibility can be limited, and thus, their effectiveness can be reduced. This subject has been widely discussed in the past recent years by various authors (Barba et al., 2017; CarbonellCapella, Buniowska, Barba,Esteve, \& Frígola, 2014; Granato, Nunes, \& Barba, 2017).

\section{Autoxidation of foodstuffs}

Oxidation, free radical formation and scavenging reactions occur not only in the human body, but virtually in every living organism and biological systems. Thus, food is no different, and autoxidation processes, lipid peroxidation and other types of oxidation are extremely common. Food antioxidants, added to foodstuffs have the same mission as the endogenous antioxidants of the human body, to protect the food from these attacks, conserving its organoleptic, texture and consumption safety properties.

The autoxidation in foodstuffs can take place through vitamins, namely vitamin $\mathrm{C}$ that spontaneously breaks down to dehydroascorbic acid through the ascorbate oxidase enzyme, but also vitamin $\mathrm{E}$ that becomes the tocopheroxyl radical, but most of autoxidation is verified in fat, namely unsaturated fatty acids, cholesterol and phospholipids, following the same reaction mechanism as lipid peroxidation which can either be mediated by the lipoxidase enzyme or spontaneously (Carocho \& Ferreira, 2013a; Liu, 2006; Noguchi et al., 2002). This catalytic process starts when oxygen attacks the double bonds of the fatty acid, and with the removal of a hydrogen atom forms a lipid radical $L$ - that, in contact with oxygen, once again forms the lipid peroxyl radical (LOO·). This whole process has impact on organoleptic properties and makes the food taste rancid, but also reduces color, changes its texture, reduces nutritional value and forms toxic compounds, being the end products alkynals, epoxides, ketones and malondialdehydes (Ayala, Muñoz, \& Argüelles, 2014; Baines \& Seal, 2012; Chen, Gonzalez, Shou, \& Chung, 1998). Among animal foodstuffs, fish is the most susceptible to autoxidation of fats, due to the high content in unsaturated fatty acids and the higher probability of having transition metals in their flesh and skin, absorbed in the aquatic systems they inhabit. In terms of vegetable foods, dried fruits and vegetable oils are the most prone to being destroyed through this phenomenon by homolytic removal of $\beta$ carbon-carbon bonds, or the formation of alkanes or alcohols. In terms of protein autoxidation, the most susceptible aminoacids are cysteine, methionine, lysine, arginine, histidine, tryptophane, valine, serine and proline with damages coming from metal-ion interactions, photochemical reactions and carbonyl groups (Deans, Fu, Stocker, \& Davies, 1997; Decker, Elias, \& McClements, 2010). Food antioxidants are used to avoid, among others, autoxidation and oxidation of foodstuffs, but stabilizing lipids and other food compounds, avoiding their cascade of oxidative reactions, but also halting these reactions when they cannot be all avoided.

\section{Food additives and legislation}

Food additives are molecules which are introduced in foodstuffs to carry out specific technologic functions, which can vary from conserving the food, imparting color, taste, sweetening, texturizing, among others. They are added during the manufacture of the food and all steps of production and introduction in the foodstuff are strictly controlled. The three most important governing bodies that legislate, enforce the law and supervise approval and regulation of food additives in the world are the EFSA, European Food Safety Authority, in the European Union (EU), and the FDA, Food and Drug Administration of the United 
States of America. Other important organisms that evaluate safety risks, carry out studies, issue statements and are overall involved with food additives is the JECFA, Joint Food and Agriculture Organization (FAO)/ World Health Organization (WHO) Expert Committee on Food Additives, and the Codex Alimentarius. Within the EU, under the supervision of the EFSA, food additives are divided into 6 groups, with specific expected outcomes in the food. The groups are: preservatives, nutritional additives, coloring agents, flavoring agents, texturizing agents, and miscellaneous agents. Each food additive is attributed a number, which relates to the group it belongs to, preceded by the letter "E", representing Europe. The added quantity of each additives is strictly calculated for each foodstuff, so the overall daily consumption by an individual does not exceed the Admissible Daily Intake (ADI), which is the cumulative amount of a specific additive that consumed everyday does not have any hazardous effect on health (Carocho, Barreiro, Morales, \& Ferreira, 2014; Carocho, Morales, \& Ferreira, 2015; Carocho, Morales, \& Ferreira, 2017).

One of the most important groups of additives are the preservatives, their E numbers range from E200 to E399. The preservatives are subdivided into three smaller functional groups, namely the antimicrobials, antioxidants and antibrowning agents. Antimicrobials are added for two purposes, to control natural spoilage and to avoid contamination by microorganisms. Antibrowning agents are used to prevent browning, which typically occurs during handling processing and storage. Browning phenomena take place through two paths, the enzymatic and the non-enzymatic browning. I the enzymatic browning, polyphenol oxidase catalyzes the conversion of phenols to quinones, sequentially darkening the food. Non-enzymatic browning occurs in sugar caramelization and Maillard reactions between carbonyl and free amino groups. Finally, the antioxidant subgroup of additives is used to extend the shelf life of foodstuffs by protecting the food from becoming rancid, losing color, developing odours, losing texture, among other phenomena that take place in food products. The reactions that protect the food are the same ones that protect cells in biological organisms, like the ones detailed above, and have a specific aim, to avoid oxidation, allowing the food to be in good conditions for a longer time (Carocho et al., 2014, 2015).

\section{EFSA approved food antioxidants}

Table 1 details all the food antioxidants that are approved by EFSA, as well as their group, E number, name, and the most recent corresponding official document that details the safety concerns and other information regarding their approval.

\section{Functional antioxidant groups}

Within the subgroup of antioxidants, there are clusters of molecules that are grouped to further simplify the understanding of the large number of compounds and the foods they are allowed in. With the increasing interest for natural food additives, some scientists defend that there should be a separation between the synthetic/artificial food additives and the natural ones, but this has not been done. Thus, the natural and synthetic provenance of antioxidants are not stated in the official tables that display the quantities and permissions of use of each additive in each food type.

The groups of antioxidant food additives are:

\subsection{Ascorbates (E300 - E304)}

The ascorbate group is composed of ascorbic acid (E300), sodium ascorbate (E301), calcium ascorbate (E302) and fatty acids esters of ascorbic acid (E304), being ascorbic acid the most widespread of the group, but also one of the most widespread antioxidants in foodstuffs. Ascorbic acid and its monoanion ascorbate are very strong antioxidants, both within the human body by neutralization of free radicals, but also
Table 1

List of EFSA approved food antioxidants, their class, E number, name and the most recent EFSA approval document.

\begin{tabular}{|c|c|c|c|}
\hline Additive Group & E Number & Name & $\begin{array}{l}\text { Official } \\
\text { Document }\end{array}$ \\
\hline \multirow[t]{4}{*}{ Ascorbates } & 300 & Ascorbic acid & EFSA, 2015a \\
\hline & 301 & Sodium ascorbate & EFSA, 2015a \\
\hline & 302 & Calcium ascorbate & EFSA, 2015a \\
\hline & 304 & $\begin{array}{l}\text { Fatty acids esters of ascorbic } \\
\text { acid }\end{array}$ & EFSA, 2015b \\
\hline \multirow[t]{4}{*}{ Tocopherols } & 306 & Tocopherol-rich extract & EFSA, 2015c \\
\hline & 307 & Alpha-tocopherol & EFSA, 2015c \\
\hline & 308 & Gamma-tocopherol & EFSA, 2015c \\
\hline & 309 & Delta-tocopherol & EFSA, 2015c \\
\hline \multirow[t]{3}{*}{ Gallates } & 310 & Propyl gallate & EFSA, 2014a \\
\hline & 311 & Octyl gallate & EFSA, 2015d \\
\hline & 312 & Dodecyl gallate & EFSA, 2015e \\
\hline \multirow[t]{2}{*}{ Erythrobates } & 315 & Erythorbic acid & EFSA, 2016a \\
\hline & 316 & Sodium erythorbate & EFSA, 2016a \\
\hline \multirow[t]{3}{*}{ Butylates } & 319 & $\begin{array}{l}\text { Tertiary-butyl } \\
\text { hydroxyquinone (TBHQ) }\end{array}$ & EFSA, 2016b \\
\hline & 320 & $\begin{array}{l}\text { Butylated hydroxyanisole } \\
\text { (BHA) }\end{array}$ & EFSA, 2011 \\
\hline & 321 & $\begin{array}{l}\text { Butylated hydroxytoluene } \\
\text { (BHT) }\end{array}$ & EFSA, 2012 \\
\hline \multirow[t]{3}{*}{ Lactates } & 325 & Sodium lactate & EFSA, 2008 \\
\hline & 326 & Potassium lactate & JECFA, 2006a \\
\hline & 327 & Calcium lactate & JECFA, 2006b \\
\hline \multirow[t]{5}{*}{ Citrates } & 330 & Citric acid & JECFA, 2014 \\
\hline & 331 & Sodium citrates & JECFA, 2006c \\
\hline & 332 & Potassium citrates & JECFA, 2006d \\
\hline & 333 & Calcium citrates & JECFA, 2007 \\
\hline & 380 & Triammonium citrate & JEFCA, 2006e \\
\hline \multirow[t]{6}{*}{ Tartrates } & 334 & Tartaric acid $(\mathrm{L}(+)-)$ & JECFA, 2006f \\
\hline & 335 & Sodium tartrates & JECFA, 2009 \\
\hline & 336 & Potassium tartrates & JECFA, $2006 \mathrm{~g}$ \\
\hline & 337 & Sodium potassium tartrate & JECFA, $2006 \mathrm{~g}$ \\
\hline & 353 & Metatartaric acid & $\begin{array}{l}\text { Commission } \\
\text { Regulation, } 2011\end{array}$ \\
\hline & 354 & Calcium tartrate & $\begin{array}{l}\text { Commission } \\
\text { Regulation, } 2011\end{array}$ \\
\hline \multirow[t]{5}{*}{ Phosphates } & 338 & Phosphoric acid & JECFA, 2006h \\
\hline & 339 & Sodium phosphates & $\begin{array}{l}\text { JECFA, 2006i } \\
\text { JEFCA, 2006j } \\
\text { JEFCA, 2006k }\end{array}$ \\
\hline & 340 & Potassium phosphates & $\begin{array}{l}\text { JEFCA, 2006l } \\
\text { JEFCA, 2006m } \\
\text { JEFCA, 2006n }\end{array}$ \\
\hline & 341 & Calcium phosphates & $\begin{array}{l}\text { JEFCA, 2006o } \\
\text { JEFCA, 2006p } \\
\text { JEFCA, 2006q }\end{array}$ \\
\hline & 343 & Magnesium phosphates & $\begin{array}{l}\text { JEFCA, } 2008 \\
\text { JEFCA, 2006r } \\
\text { JEFCA, 2006s }\end{array}$ \\
\hline \multirow[t]{3}{*}{ Malates } & 350 & Sodium malates & $\begin{array}{l}\text { JEFCA, 2006t } \\
\text { JEFCA, 2006u }\end{array}$ \\
\hline & 351 & Potassium malates & $\begin{array}{l}\text { Commission } \\
\text { Regulation, } 2011\end{array}$ \\
\hline & 352 & Calcium malates & JEFCA, 2006v \\
\hline \multirow[t]{3}{*}{ Adipates } & 355 & Adipic acid & $\begin{array}{l}\text { Commission } \\
\text { Regulation, } 2011\end{array}$ \\
\hline & 356 & Sodium adipate & $\begin{array}{l}\text { Commission } \\
\text { Regulation, } 2011\end{array}$ \\
\hline & 357 & Potassium adipate & $\begin{array}{l}\text { Commission } \\
\text { Regulation, } 2011\end{array}$ \\
\hline EDTA & 385 & $\begin{array}{l}\text { Calcium disodium ethylene } \\
\text { diamine tetra-acetate } \\
\text { (Calcium disodium EDTA) }\end{array}$ & $\begin{array}{l}\text { Commission } \\
\text { Regulation, } 2011\end{array}$ \\
\hline Rosemary & 392 & Extracts of rosemary & EFSA, 2015f \\
\hline
\end{tabular}

in foodstuffs, where they are used as antioxidants to avoid oxidation of the food and its eventual spoilage. It has a water solubility at $25{ }^{\circ} \mathrm{C}$ of $330 \mathrm{~g} / 100 \mathrm{~mL}$. The different derivatives of ascorbic acid are detailed in Table 2. Ascorbic acid is a cyclic ester with a ketone in position $\alpha$, and has the ability to donate two electrons to molecules around it, becoming oxidized, known in this form as dehydroascorbic acid. It is allowed to 
Table 2

Ascorbic acid and their derivatives, structures, admissible daily intake and $\mathrm{E}$ numbers, adapted from the Commission Report, 2001.

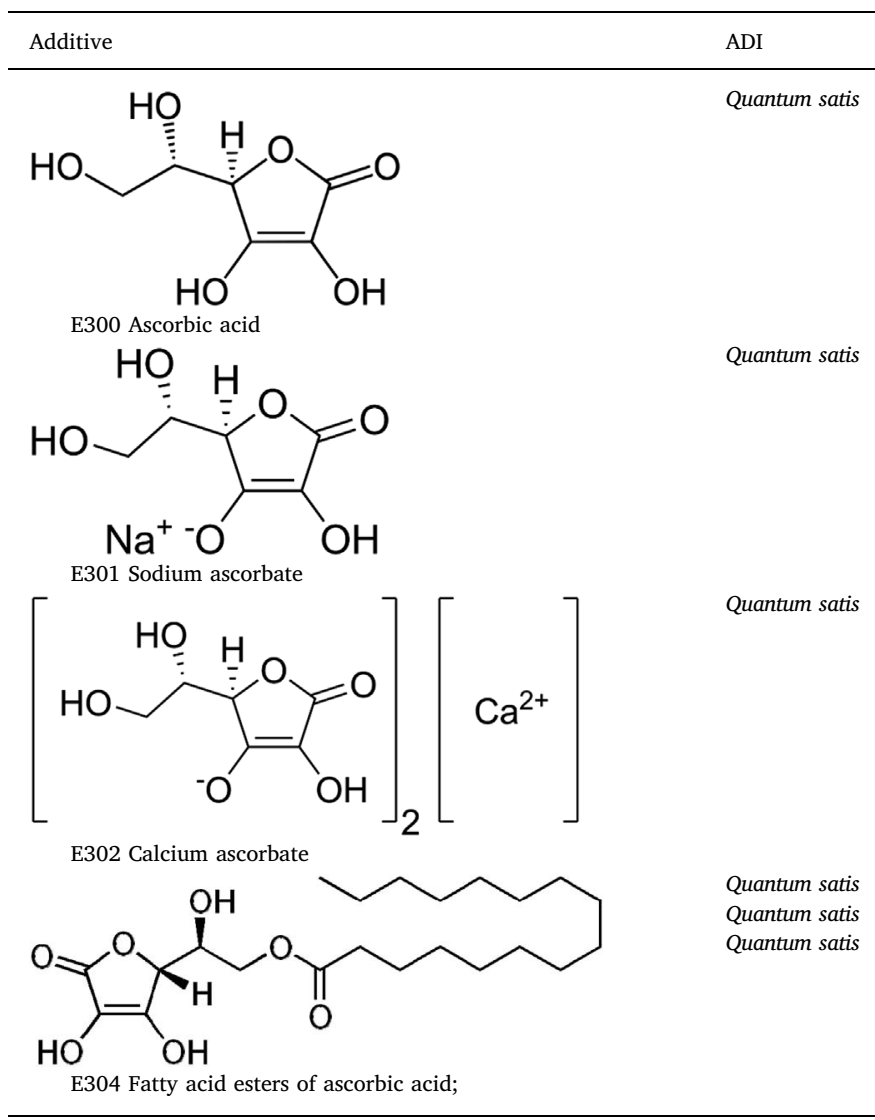

be used as an antioxidant, in virtually every country in the world. In the EU it takes on the E300 number and in the United States of America (USA) it integrates the Generally Regarded as Safe (GRAS) list, in which additives and ingredients are added when their consumption poses no threat to consumers. Furthermore, it is also contemplated in the Everything Added to Food in the United States (EAFUS) list, the entry number CAS 50-87-7. Usually, ascorbic acid can be found combined with synthetic antioxidants like butylated hydroxytoluene (BHT) and butylated hydroxyanisole (BHA) to further increase their antioxidant capacity given the excellent properties of ascorbic acid to regenerate other antioxidants. Another strong association it establishes is with tocopherols, in which these compounds are regenerated from their tocopheroxyl radical form back to tocopherols through the donation of electrons from ascorbic acid. In 2015, the European Food Safety Authority (EFSA) which supervises food safety within the European Union (EU) reviewed the levels of exposure of ascorbic acid and it salts (sodium ascorbate E301 and calcium ascorbate E302) and further determined that there was no need to define an ADI because the daily consumption of either did not pose any threat (Baines \& Seal; EFSA, 2015a). Sodium ascorbate can be used as an antioxidant in various foods, but it has been tested in dry fermented sausages to avoid protein and lipid oxidation, as a manner of reducing the use of nitrites in smoked or fermented meat, which are known to have carcinogenic effects. Sodium ascorbate is quite successful at reducing oxidation, but is also responsible for pro-oxidant behaviour, thus not being widely used as a substitute for nitrites in food (Berardo et al., 2016).

Calcium ascorbate, another compound from the ascorbate family is used as an antioxidant in dairy products, cured or cooked meat products, to dip freshly cut fruit and avoid browning, while also being used to intensity the color of cured meat and act as a synergistic to other antioxidants (Aguayo, Requejo-Jackman, Stanley, \& Woolf, 2010;
Gimeno, Astiasarán, \& Bello, 2001; Sofos \& Busta, 1980; Wang, Feng, \& Luo, 2007).

Fatty acids esters of ascorbic acid are the least used additive of the ascorbates subgroup, although it has a wide range of foods it can be used in, namely dairy products, chewing gum, cereals, meats, desserts, salads, sauces and others (EFSA, 2015b). Both derivatives have a lower solubility in water that ascorbic acid, of $62 \mathrm{~g} / 100 \mathrm{~mL}\left(25^{\circ} \mathrm{C}\right)$ for sodium ascorbate and $50 \mathrm{mg} / 100 \mathrm{~mL}$ for calcium ascorbate.

All the additives of the ascorbates are considered quantum satis, thus no ADI being defined for their consumption.

\subsection{Tocopherols (E306 - E309)}

The tocopherol group allowed by the EFSA encompasses three of the four isoforms of tocopherols, $\alpha$-, $\beta$-, and $\gamma$-tocopherol, as well as a tocopherol rich extract, being $\delta$-tocopherol the only isoform that is not allowed to be used as an isolated additive in food. The first report of the name vitamin E, which represents all the isoforms was in 1925, three years before it was discovered and called factor X. Tocotrienols, first thought to be other isoforms of tocopherols, were only called tocotrienols when higher unsaturation was found on their side chains. In terms of activity, $\alpha$-tocopherol is the most active isoform, followed by $\beta$-, $\gamma$-, and finally $\delta$-tocopherol. These compounds have a chroman ring and a phytyl chain (a hydrocarbon chain with methyl residues). In Europe, they are allowed to be used in meat and lactic products, oils, but also in coatings. Their main aim are foods with high quantity of lipids, given they are the most potent lipophilic antioxidants. Tocopherols have very important synergistic behaviour with ascorbic acid, in which ascorbic acid regenerates tocopherols, but also with carotenoids, where both are regenerated by the other co-antioxidant, although regeneration of carotenoids by tocopherols is preferred. All forms of tocopherols are insoluble in water. Other synergists of tocopherols are phosphatidylinositol and quercetin. Tocopherols also have antagonists, namely rosmarinic acid and caffeic acid (Barbosa-Pereira et al., 2013; Carocho et al., 2015; Choe \& Min, 2009; Lin \& Pascall, 2014; Marcos, Sarraga, Castellari, Kappen, Schennik, \& Arnau, 2014; Seppanen, Song, \& Csallany, 2010; Smith \& Hong-Shum, 2003; Wang et al., 2015).

\subsection{Gallates (E310 - E312)}

The term gallates usually refers to the propyl, octyl, and dodecyl esters of gallic acid, which is a hydroxybenzoic acid. All three of these compounds are approved for use in the EU, propyl gallate (E310), octyl gallate (E3111), and dodecyl gallate (E312), represented in Table 3. Propyl gallate is the most used of the three gallates approved by the EFSA, with an ADI of $1.4 \mathrm{mg} / \mathrm{kg}$ day, and has been used since 1948, used both as a food additive but also in coatings and packages. It is an ester from gallic acid with propanol, and its main function is avoiding lipid peroxidation, but also aids in the maintenance of organoleptic properties, freshness, aroma and color. It can be used alone or in combination with BHT and BHA, and even with citric acid to reduce the dark coloration produced due to the combination with iron. In the USA, it is considered GRAS and included in the EAFUS with the access number 121-79-9. Propyl gallate has a very low solubility, under $1 \mathrm{mg} /$ $\mathrm{mL}$ of water $\left(20^{\circ} \mathrm{C}\right)$. Octyl and dodecyl gallate are less used, but they are also found in the JECFA database with access numbers 1034-01-1 and 1166-52-5, although no ADI has been allocated for any of them (Branen, Davidson, \& Thorngate, 2001; EFSA, 2014b; Gálico, Nova, Guerra, \& Bannach, 2015; Heijden, Janssen, \& Strik, 1986; Jacobi, Eicke, \& Witte, 1998; Zurita et al., 2007).

Octyl gallate is used as an antioxidant, an antimicrobial, especially against Gram + bacteria, but also as an antifungal agent. Although its application is limited to specific cases and very limited, octyl gallate can be used in dehydrated milk, fats, oils, nut butters, potato products, chewing gum, cereals, meat, nuts and food supplements. It is insoluble 
Table 3

Gallates structures and their ADI's.

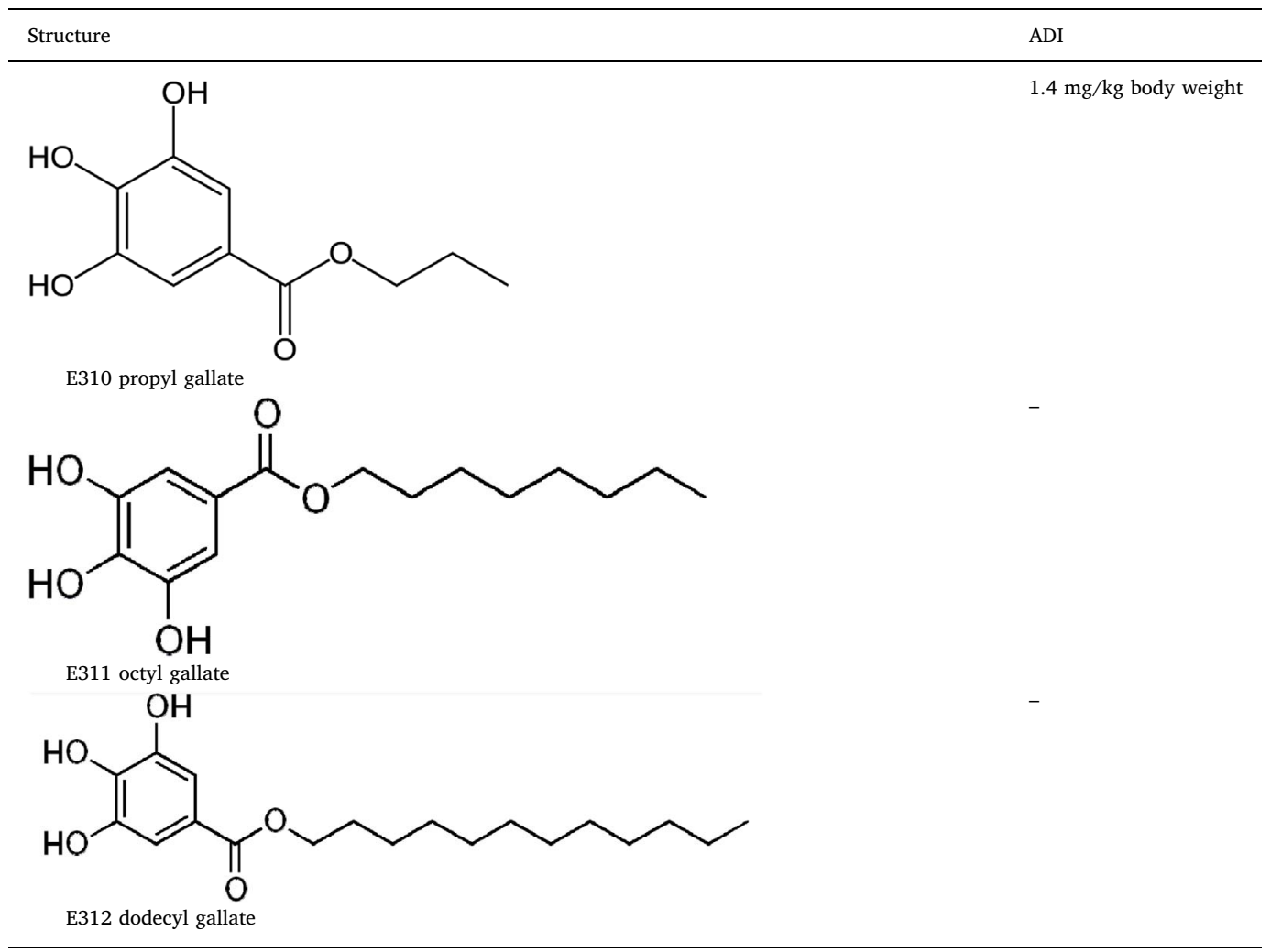

in water, but freely soluble in ethanol, as is dodecyl gallate. (EFSA, 2015d; Fujita \& Kubo, 2002; Hsu, Chang, \& Chang, 2007; Kubo, Xiao, \& Fujita, 2001).

Dodecyl gallate, the final compound of the gallates class is one of the compounds of green tea, and due to having hydroxyl and carboxyl groups in it structure, shows antioxidant activity. As the other compounds in this class it also has antimicrobial activity, and can be used in the same types of food as the other compounds of this subgroup (Kubo, Muroi, \& Kubo, 1993; Kubo, Masuoka, Xiao, \& Haraguchi, 2002; Kubo, Fujita, Nihei, \& Masuoka, 2003; Maesk, Chrzescijanska, Zaborski, \& Piotrowska, 2014; EFSA, 2015e).

\subsection{Erythrobates (E315 - E316)}

The Erythorbates subgroup is comprises two compounds, erythorbic acid (E315) and sodium erythorbate (E316). Erythorbic acid is a stereoisomer of ascorbic acid, differing only on relative position of the hydroxyl groups and the hydrogen of the fifth carbon. They have basically the same function, although the antiscorbutic activity of erythrobic acid if below ascorbic, and the same is verified for collagen synthesis, although proline hydroxylation stimuli is the same (Fidler, Davidsson, Zede, \& Hurrel, 2004; Miura, Yazama, \& Tai, 2015). In the USA, erythrobic acid has benefited from the banning of sulphites in salads, and has acted as a substitute for these. This compound is mostly consumed (80\%) as sodium erythrobate (E316), namely in cured meat, frozen fruit, vegetables, oils, fats, shellfish, fish, in many with the function of reducing the formation of nitrosamines during curing or cooking (Hui, 2006). Sodium erythorbate is a stereoisomer of sodium ascorbate and displays antioxidant activity by singlet oxygen quenching, hydrogen donation and as a reducing agent. Erythorbic acid has a solubility in water, at $25{ }^{\circ} \mathrm{C}$, of $40 \mathrm{~g} / 100 \mathrm{~mL}$, while sodium erythorbate only has a solubility of $16 \mathrm{mg} / 100 \mathrm{~mL}$ (Figueirêdo, Trad, Mariutti, \& Bragagnolo, 2014; Hsu \& Sun, 2006).

\subsection{Butylates (E319 - E321)}

Butylates are among the most used antioxidants, comprised of tertbutylhydroquinone (TBHQ - E319), butylated hydroxyanisole (BHA E320) and butylated hydroxytoluene (BHT - E321).

TBHQ is a widespread antioxidant additive with an ADI of $0.7 \mathrm{mg} /$ $\mathrm{kg}$, and main application in cereals, margarines, meats and oils (Table 4). It is usually used in synergism with other antioxidants, namely BHT, citric acid, although it cannot be used with propyl gallate. One of its main advantages when compared to other counterparts is the fact it does not lose color when in contact with iron and other metals, but it is not effective in bread and pastry industries. TBHQ is practically insoluble in water (Branen et al., 2001; EFSA, 2004; Gharavi \& El-Kadi, 2005; Smith \& Hong-Shum, 2003).

BHA is a widespread artificial antioxidant of phenolic nature, with the E number 320 (Table 4) and a water solubility of less than $1 \mathrm{mg} / \mathrm{mL}$ at $20{ }^{\circ} \mathrm{C}$. It is used both in foods and their coatings, but has a very low solubility in water and a strong phenolic odour, which limits its use. In 2012, the EFSA's panel of food additives concluded that the exposure to BHA as a food additive did not exceed the ADI of $1 \mathrm{mg} / \mathrm{kg}$ of body weight, even for the highest consuming population, but, this ADI was exceeded when the combined exposure as food additive and food contact material was taken into consideration. The target of BHA is controlling rancidification of animal fat in foodstuffs, given its low effectiveness on vegetable fat (Branen et al., 2001; EFSA, 2011; Roushani \& Sarabaegi, 2014; Wang et al., 2015).

BHT is the final compound of the butylated class of antioxidants, being widely used, one of the cheapest to produce, and used in combination with gallates and BHA (Table 4). By having three tert-butyl groups it displays a higher steric hindrance than BHA. BHT, as BHA is not soluble in water, but has a great solubility in fat, and is stable at high temperatures, thus being used in food that have to be baked or boiled. EFSA reviewed consumers exposition to BHT, which has an ADI of $0.5 \mathrm{mg} / \mathrm{kg}$ body weight, and determined that there was no risk of 
Table 4

Main synthetic antioxidants and their ADI.

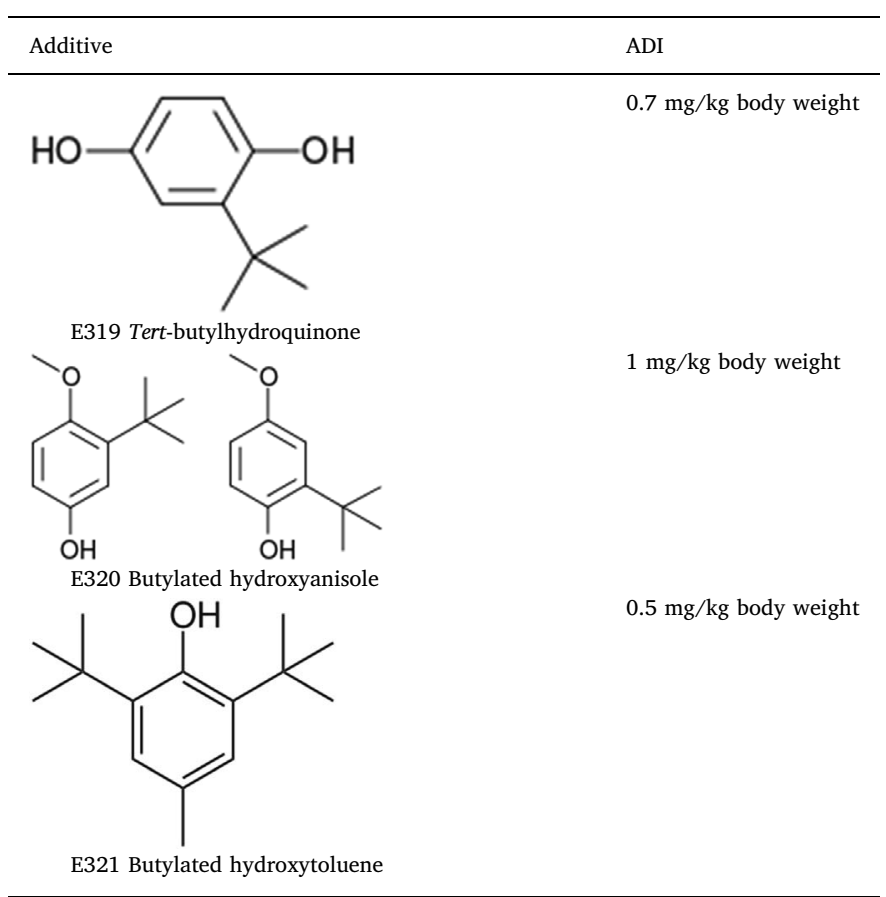

over exposure through the diet. It has a water solubility of under $1 \mathrm{mg} /$ $\mathrm{mL}$ at $25{ }^{\circ} \mathrm{C}$ (Branen at el., 2012; EFSA, 2012; Ma, Pan, Zhang, \& Zhang, 2013).

BHA and BHT have synergic behaviours when added together in foodstuffs. Initially, BHA interacts with peroxyl radicals, becoming the phenoxy radical of BHA, that then uses BHT to regenerate itself before neutralizing new radicals in the food (Akoh \& Min, 2002).

\subsection{Lactates (E270, E325-E327)}

Lactates are compounds with various functions, namely as antioxidants, antimicrobials, color enhancers and stabilizers, flavorings, $\mathrm{pH}$ regulators, humectants, but also work as antioxidant synergic compounds. All of these additives are derived from lactic acid (E270, solubility in water at $25{ }^{\circ} \mathrm{C}-100 \mathrm{mg} / \mathrm{mL}$ ) and are usually used in dairy products, vegetables and meat. Of this group, the most important additives are sodium lactate (E325), potassium lactate (E326) and calcium lactate (E327). Sodium lactate is used as an antimicrobial in sausages, meat patties, fish, and is further considered a GRAS in the USA. Its applicability is reduced by the water activity inside a foodstuff, while also having a low solubility, of just over $1.5 \mathrm{mg} / \mathrm{mL}$ at $25{ }^{\circ} \mathrm{C}$. Synergies are established with salt, ascorbic acid, nisin, and thymol (Brewer, Mckeith, Martin, Dallmier, \& Meyer, 1991; Branen et al., 2001; Crist et al., 2014; Ilhak \& Guran, 2014; Maca, Miller, \& Acuf, 1997; Naidu, 2000; Nnanna, Ukuku, McVann, \& Shelef, 1994; Nykänen, Weckman, \& Lapveteläinen, 2000; Papadopoulos, Miller, Acuff, Vanderzant, \& Cross, 1991; Sallam \& Samejima, 2004; Sallam, 2007; Schelegueda, Gliemmo, \& Campos, 2012; Weaver \& Shelef, 1993; Wit \& Rombouts, 1990).

Potassium lactate is also used in processed and unprocessed meats, sausages and patties. It works by reducing water activity and by combination with antioxidants and antimicrobials, as sodium diacetate and calcium ascorbate (Bradford et al., 1993; Kim et al., 2009a; Kim et al., 2009b; Stekelenburg \& Kant-Muermans, 2001).

Calcium lactate is another synergistic compound that is used to inhibit food browning, namely in fruits, maintaining their structure and conferring antimicrobial activity. It is synergistically applied to phosphates to improve their antioxidant capacity in meat, and can hypothetically activate the calpain enzyme. It is very soluble in water.
(Alandes, Hernando, Quiles, Pérez-Munuera, \& Lluch, 2006; Cruzen et al., 2015; Hernández-Muñoz, Almenar, Ocio, \& Gavara, 2006; Kim, Huff-Lonergan, \& Lonergan, 2012; Kim et al., 2009a; Luna-Guzmán \& Barrett, 2000; Manganaris, Vasilakakis, Diamantidis, \& Mignani, 2005).

\subsection{Citrates and tartrates (E330-E333; E380)}

Citrates are salts of citric acid (E330), one of the most abundant compounds in lemons and other citric fruits. Beyond being very important for the biological pathways of the human body, it is also a very important food additive, and a very strong synergist, namely with ascorbic acid and chitosan. It is also a chelating agent, inhibiting food browning and increasing its shelf life. Its solubility varies greatly with temperature, but as a reference, at $20^{\circ} \mathrm{C}$, its solubility is $147.76 \mathrm{~g} /$ 100 mL (De'Nobili, Soria, Martinefski, Tripodi, Fissore, \& Rojas, 2016; Liu, Liu, Yuan, Zhong, \& Chen, 2016). Other compounds from this group are sodium citrate (E331), potassium citrate (E332), and calcium citrate (E333). Sodium citrate is a GRAS that has many functions as a food additive, namely as a chelating agent, $\mathrm{pH}$ buffer, retardant, antimicrobial, flavor enhancer and antioxidant. It has synergistic effect with organic acids, namely citric, tartaric, malic and lactic. It is mainly employed in meats and skimmed milk (Banipal, Kaur, Kaur, \& Banipal, 2016; Hui, 2006; Naidu, 2000; Stekelenburg \& Kant-Muermans, 2001).

Potassium citrate is an emulsifying agent, $\mathrm{pH}$ buffer, sequestrant and antioxidant, that is used to change intense flavors (acids), with applicability in gelatine, marmalade and cheese. Its water solubility is around $153 \mathrm{~g} / 100 \mathrm{~mL}$ at $25{ }^{\circ} \mathrm{C}$. (Branen et al., 2001).

Finally, calcium citrate has the same properties than potassium citrate being used in the same foods, but also in baby food. Solubility at $25{ }^{\circ} \mathrm{C}$ in water is around $0.95 \mathrm{~g} / 100 \mathrm{~mL}$ (Smith \& Hong-Shum, 2003).

\subsection{Tartrates (E334 - E337; E353 - E354)}

Tartrates are derivatives of tartaric acid with the sodium, potassium and calcium salts being the additives allowed for use in the EU, having the E335, E336 and E337 numbers, respectively, while also being considered GRAS. Tartaric acid is a flavor enhancer, acidity regulator and antioxidant. These additives are all used in chocolate, marmalades, gelatines, canned goods and fresh pasta (Vickers, Braybrook, Lawrence, \& Gray, 2007). Sodium and potassium tartrates are further used in cheese, fats, oils, meat and sausages (Branen et al., 2001).

\subsection{Phosphates (E338-E345)}

Commonly known as phosphates, the salts of phosphoric acid have many applications as food additives. Apart from the high consumption of phosphates being related to kidney diseases, the highest contributor to their increase in consumption is the fast-food industry (Ritz, Hahn, Ketteler, Kuhlmann, \& Mann, 2012). Still phosphoric acid and its salts represent $25 \%$ of all acids used in the food industry, namely as a $\mathrm{pH}$ buffers, chelating agents, antioxidants and acidification agents. They establish synergisms with citric acid and lauryl gallate to avoid fat oxidation, and are used in refreshments, fruits gelatine, cheese and powdered yeasts. Phosphoric acid has a very high solubility in water, which varies with temperature. At $14.95{ }^{\circ} \mathrm{C}$, it has a solubility value of 446 g/100 mL (Belitz, Grosch, \& Schieberle, 2009; Hui, 2006).

Sodium phosphate (E339) is used in foods for its antioxidant, sequestrant, water retainer and antimicrobial properties, while also being considered a GRAS compound in the USA. Used in pasta, meat, powdered milk, fruit, cheese, chips and ready to eat desserts, it establishes synergistic behaviour with nisin to increase its chelating and antimicrobial effects. It is available under the monosodium, disodium and trisodium forms. Its solubility in water is $11.8 \mathrm{~g} / 100 \mathrm{~mL}$ at $25{ }^{\circ} \mathrm{C}$ (Baines \& Seal, 2012; Branen et al., 2001; Hui, 2006; Msagati, 2013; Naidu, 2000).

Potassium phosphate (E340), also a GRAS molecule, claimed to be 
freely soluble in water, it is used in meat, bread, dough, powdered juices, eggs, pasta and sausages. It establishes synergisms with sodium acetate when employed to preserve catfish steaks (Branen et al., 2001; Naidu, 2000; Smith \& Hong-Shum, 2003).

Calcium phosphate (E241), another GRAS molecule is used as an acidulant, leavening agent, antioxidant, humectant, and anti-caking agent. It is used in mixtures of additives for the baking industry, but also in canned fruit, powdered juices, flour, cheese and baby food. Contrary to the other salts of phosphoric acid, calcium phosphate is very insoluble in water. (Branen et al., 2001; Hui, 2006; Msagati, 2013; Naidu, 2000; Smith \& Hong-Shum, 2003).

Finally, ammonium phosphate (E342) and magnesium phosphate (E343) are other additives derived from phosphoric acid with less expression in the food industry, although also being considered GRAS. They can be used in bread, pasta, biscuits and pancakes, but only ammonium phosphate is soluble in water, with a value of $69.5 \mathrm{~g} / 100 \mathrm{~g}$ at $25{ }^{\circ} \mathrm{C}$ (Branen et al., 2001).

\subsection{Malates (E350 - E352)}

Malates are a group of molecules that derive from malic acid, namely esters and other salts. Although this group of compounds are considered in the antioxidant section of the additive tables, their main functions are as acidity regulators, flavoring agents, buffering agents, humectants and seasoning agents, rather than antioxidants. Furthermore, very scarce information is available from these compounds, apart from their data, composition, purity and test sheets. Malic acid (E350) has a water solubility, at $20{ }^{\circ} \mathrm{C}$, of $55.8 \mathrm{~g} / 100 \mathrm{~mL}$, while calcium malate (E352) is only slightly soluble in water.

\subsection{Adipates (E355 - E357)}

Adipic acid is another organic acid with various application in the food industry. It is used as and antimicrobial, antioxidant, $\mathrm{pH}$ buffer, and gelling agent. Applications for this compound and its salts are in cheese, marmalades and canned fruits. It is used in synergism with sodium metabisulphite. Their ADI is established at $5 \mathrm{mg} / \mathrm{kg}$ body weight. Adipic acid (E355) has a variable solubility in water, which varies with temperature. At $10{ }^{\circ} \mathrm{C}$ it is about $1.4 \mathrm{~g} / 100 \mathrm{~mL}$ of water, while sodium adipate (E357) has, at $20{ }^{\circ} \mathrm{C}$, a solubility of $50 \mathrm{~g} / 100 \mathrm{~mL}$ of water. (Belitz et al., 2009; Branen et al., 2001; Smith \& Hong-Shum, 2003).

\subsection{Succinic acid (E363)}

Succinic acid is also an organic acid and GRAS molecule that is commercially prepared by hydrogenation of malic or fumaric acid. It is non-hygroscopic, but has a higher solubility than fumaric and adipic acid. Although its main function is not as an antioxidant, but rather an acidulant, it shows plastic properties, ideal for pasta, but also as a flavor enhancer and antimicrobial. Its monoglyceride esters are used in chicken meat, dairy and baked food. At $20{ }^{\circ} \mathrm{C}$, succinic acid has a solubility in water, of 5-10 mg/L (Belitz et al., 2009; Branen et al., 2001; Hui, 2006; Msagati, 2013; Smith \& Hong-Shum, 2003; Zeikus, Jain, \& Elankovan, 1999).

\subsection{Ethylenediaminetetraacetic acid (EDTA) (385)}

EDTA is a molecule with various applications in the food industry. Disodium EDTA calcium is used as an additive (E385), with and ADI of $2.5 \mathrm{mg} / \mathrm{kg}$ body weight, considered a sequestrant, metal chelating compound and antioxidant, that establishes synergies with potassium sorbate, lysozyme, nisin, monolaurin and monocapin, in order to increase the antimicrobial potential of these compounds in foods like chicken meat, processed meat, vegetables, fruit, beer and fruit juices. Furthermore, it can also connect with ascorbic and citric acid, lecithins,
BHA, BHT and PG. When combined with antioxidants, its main use is in anointing grease, but also in fresh and processed meat, fish, sauces, cereals and seafood. Its appearance is a colourless, odourless and tasteless white powder with a water solubility of $1 \mathrm{~g} / \mathrm{L}$ (Baines \& Seal, 2012; Branen et al., 2001; Hui, 2006; Igoe, 2011; Kerry \& Kerry, 2011; Msagati, 2013; Naidu, 2000; Shahidi, 2015; Smith \& Hong-Shum, 2003).

\subsection{Rosemary extracts (E392)}

Rosemary's antioxidant activities have been reported as far as the 1950 's, and its use in culinary preparations surpass that year by decades, making this plant very well and widely known for its health qualities. Rosemary extract has many polyphenols in its composition, with great antioxidant power, namely carnosic acid, rosmarinic acid, carnosol and rosmaridiphenol, among others. It has been approved for use in the EU in Annex II of Regulation No. 1333/2008, with Japan and china also approving its use in foodstuffs, defining it as "a substance mainly composed of carnosic acid, carnosol and rosmanol, obtained from the flowers and leaves of rosemary". In the EU, rosemary extract has many applications, namely dehydrated milk, fats, oils, processed potatoes, chewing gum, decorations, fine bakery, processed meat, heat treated meat, processed fish, processed eggs, mustard, soups, broths, sauces, snacks, processed nuts and food supplements, although with some restrictions within these food groups. Still, in 2015, further foodstuffs have been approved after petitions for a wider range of applications of this natural additive. It is, however, insoluble in water.

Given its safety, it has not been given an Admissible Daily Intake (ADI) value, which is given to many food additives to limit its intake be humans each day, expressed in mg per kilogram of body weight, thus being considered Quantum Satis, meaning it can be added to foodstuffs in the amount needed to carry out the intended technological task within the food, according to good manufacturing procedures. Today, rosemary extract is an example of how plant extracts (natural sources) can be used safely to conserve foodstuffs, even in synergy with other antioxidants like nisin, polyphenols, BHA and BHT, which paved the way for pursuing other sources of natural food antioxidants (Baines \& Seal, 2012; Chammem et al., 2015; EFSA, 2008; EFSA, 2015f; EFSA, 2011; Gao et al., 2014; Guo, Gao, Sun, Gão, Wang, \& Zhang, 2016; Jongberg, Tørngren, Gunvig, Skibsted, \& Lund, 2013; Yang et al., 2016).

\section{Natural food antioxidants}

There are many types of natural food antioxidants, and, among them, some of the most important groups are detailed below.

\subsection{Polyphenols}

These compounds derive from the secondary metabolism of most plants and can be divided into classes: hydroxybenzoic acids, hydroxycinnamic acids, coumarins, lignans, chalcones, flavonoids, lignins and xanthones (Fig. 3) (see Fig. 4).

Most of polyphenols have some type of biological activity, be it may anti-inflammatory, antimicrobial, antioxidant or antitumoral (Carocho \& Ferreira, 2013b). Polyphenols of natural origin can be used to stabilize oxidation processes in foodstuffs, being the most used the rosemary extract (Rosmarinus officinalis L.), salvia (Salvia officinalis L.) and oregano (Origanum vulgare L.). Only rosemary extract is included in the European list of food additives, with the E number 392 (EU Regulation $1129 / 2011$ ). Salvia extract has a higher antioxidant power than rosemary, and although most of the phenolic compounds present in both are the same, they are found in different proportions. Oregano extract has lower antioxidant capacity than the other two extracts, but has other compounds in its extract, namely apigenin and dihydroquercetin (Baines \& Seal, 2012; Shahidi, 2015; Upadhyay \& Mishra, 2014). 


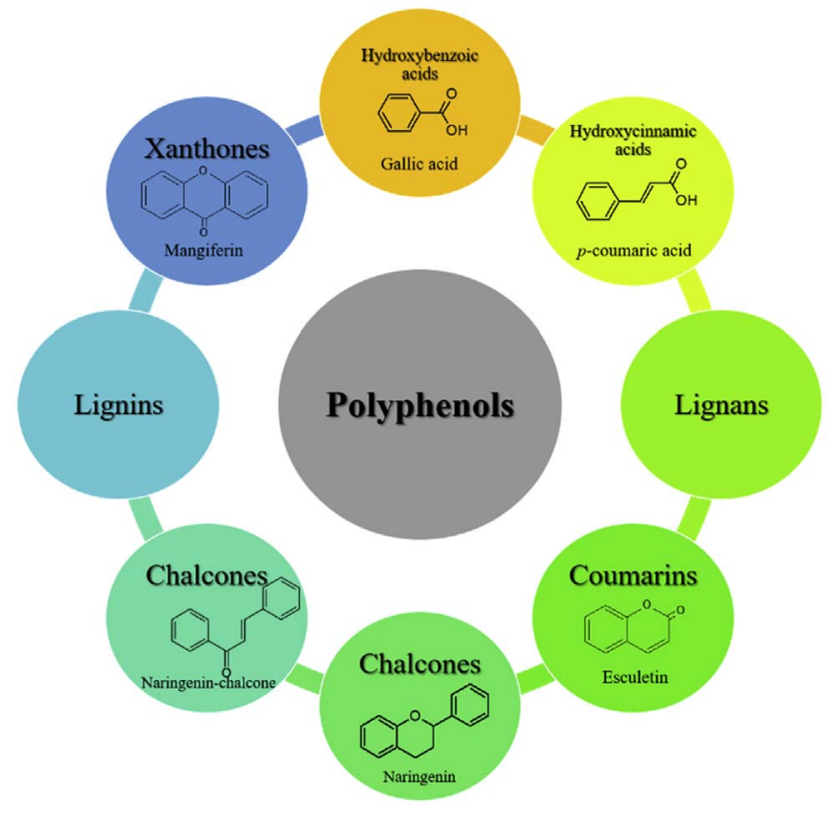

Fig. 3. Representation of the polyphenol classes, their basic structure and an example compound. Lignans and lignins basic structure are not displayed due to their enormous and complex structure. Adapted from Carocho \& Ferreira, 2013b.

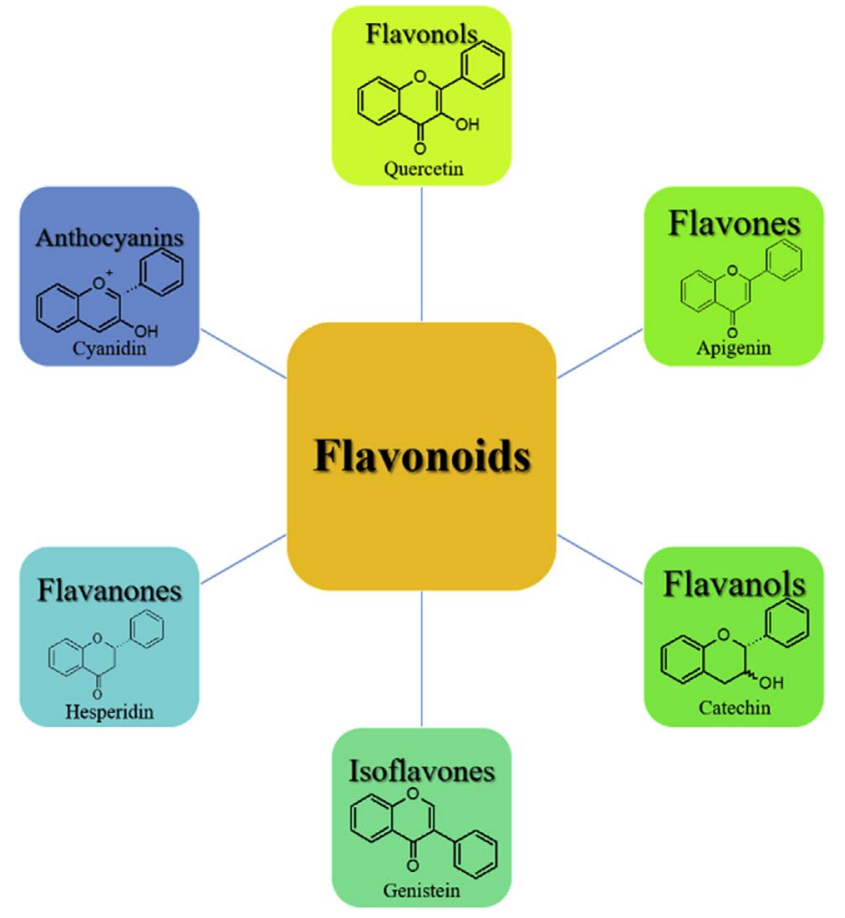

Fig. 4. Representation of the subclasses within the flavonoids class, an example of compound and the basic structure. Adapted from Carocho \& Ferreira, 2013a.

\subsection{Carotenoids (E160a-E161g)}

Carotenoids are tetraterpenes, resulting of linked isoprene units, and are responsible for imparting color to pigments. In food, their main function is as colorants, but due to their antioxidant potential, they are also used as antioxidants (Table 5). The most widespread carotenoid used the food industry is lycopene (E160), which can be used for the two purposes stated above. It is used in lactic products, fruits, fats, cereal based products, fish, meat, sauces, soups, seasonings, pastry and many other foods. One of the main drawbacks of the use of this antioxidant is the high oxidation rate it has when in contact with light (Olson, Ward, \& Koutsos, 2008; Smith \& Hong-Shum, 2003) Astaxanthin, approved as a colorant for use in the EU with the E number E161j, also has powerful antioxidant activity, and has been quite studied as a food preservative. As with all carotenoids, the most important detail of using them is maintaining their stability during storage (Martínez-Delgado, Khandual, \& Villanueva-Rodríguez, 2017).

\subsection{Annatto, bixin, norbixin}

Annatto is a mixture of many carotenoids extracted from the Bixa orellana shrub, being bixin the most important one, a carotenoid with two carboxylic acids, one of them esterified. Norbixin, derived from bixin by hydrolysis of the ester group can be acquired separately as a pigment. Interestingly, bixin in soluble in oil while norbixin is soluble in water. Annatto, despite being used as a colorant for food can also be used as an antioxidant, with reports of it use against autoxidation of triacylglycerols in seeds. Other reports claim that norbixin is a stronger antioxidant than tocopherols and can for synergistic bonds with these compounds. It is allowed to be used in the EU, having the E106b number, and an ADI of $0.065 \mathrm{mg} / \mathrm{kg}$ (Haila, Lievonen, \& Heinonen, 1996; Kiokias \& Gordon, 2003).

\subsection{Lutein (E161b)}

Lutein is another carotenoid with a wide range of biological functions, namely as an antioxidant. It is used in the cosmetic industry for its very high inhibition of lipid autoxidation in skin cells, higher than that of $\beta$-carotene. Of the 700 carotenoids, lutein and zeaxanthin are the only ones that can enter specific organs, while only a few dozen can actually enter the blood stream. The two biggest drawbacks of this compound are its very low solubility in water and its bioavailability of 9\%, at most. (Bernstein et al., 2015; Kamil, Smith, Blumberg, Astete, Sabilov, \& Chen, 2016; Lakshminarayana, Aruna, Sthisha, Dharmesh, \& Baskaran, 2013; Laksminarayana, Sathish, Dharesh, \& Baskaran, 2010; Mitri, Shegokar, Hohla, Anselmi, \& Müller, 2011). Its consumption is basically through vegetables and dietary supplements, and while EFSA allows its use as a colorant, it is not allowed to be used as an antioxidant in food. It is mostly used in refreshments, baked goods, food made with bread and also as sauce and confectionaries (Baines \& Seal, 2012).

\section{Stabilization techniques}

One drawback in the use of natural antioxidants, both individual compounds or extracts, is their stability. Generally, during extraction from the source and immediately after, many antioxidant compounds immediately start degrading, which translates into a loss of activity. Examples of these compounds are polyphenols, carotenoids, terpenes, and others.

During the previous decade, many techniques have been used to extract compounds with the least degradation, making their stabilization after extraction one of the most important challenge for a widespread use of natural compounds as food antioxidants. Loss of activity can occur at elevated temperatures, making water, air, oil and waves the responsible agents for that loss, while when it is processed at ambient temperatures, enzymes, chemicals and the passage of time are the responsible factors. Examples of treatments that can reduce antioxidant activity are pasteurization, sterilization, blanching, evaporation, extrusion, drying, roasting, baking, frying, microwaving, application of infra-red light, cutting, smoking and storing (even when frozen).

The most common ways of overcoming loss of efficacy of antioxidants if by combining additives with a proper packaging, either through conventional packaging (high price and good protection), vacuum packaging with inert gas (high price and good protection), using oxygen scavengers in the package (higher price and only satisfactory results), and finally the addition of more antioxidants in the package 
Table 5

Main carotenoids and their admissible daily intakes (Commission Report, 2001).

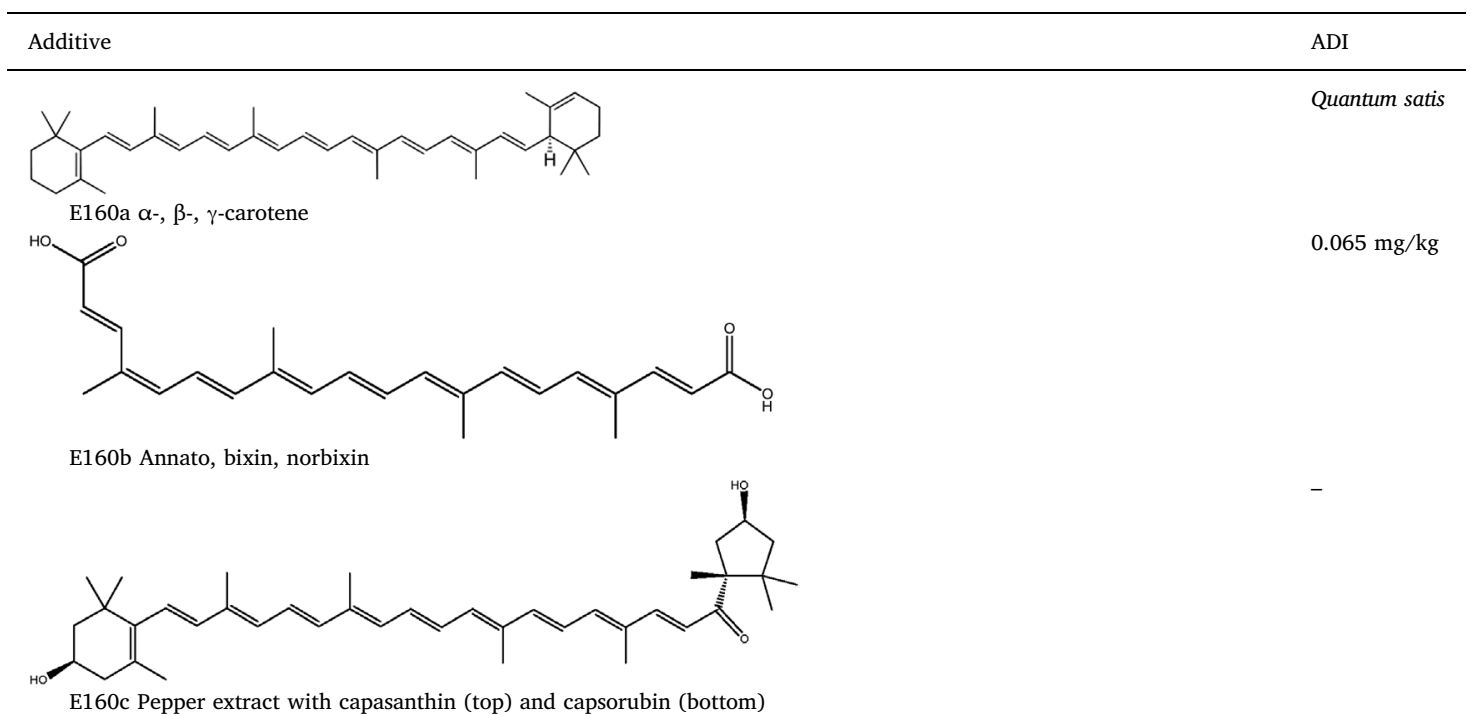<smiles>CC(/C=C/C=C(C)/C=C/C=C(C)/C=C/C(=O)[C@@]1(C)C[C@@H](O)CC1(C)C)=C\C=C\C=C(C)\C=C\C(=O)[C@@]1(C)C[C@@H](O)CC1(C)C</smiles>

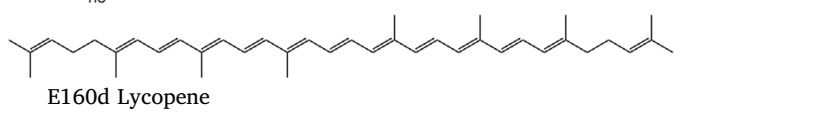<smiles>CC(C=O)=CC=CC(C)=CC=CC=C(C)C=CC=C(C)C=CC1=C(C)CCCC1(C)C</smiles>

E106e $\beta$-apo-8'-carotenal<smiles>CCOC(=O)/C(C)=C/C=C/C(C)=C/C=C/C=C(C)/C=C/C=C(C)/C=C/C1=C(C)CCCC1(C)C</smiles><smiles>CC1=C[C@H](O)CC(C)(C)[C@H]1/C=C/C(C)=C/C=C/C(C)=C/C=C/C=C(C)/C=C/C=C(C)/C=C/C1=C(C)C[C@@H](O)CC1(C)C</smiles><smiles>CC(C=CC=CC(=O)[C@@]1(C)C[C@@H](O)CC1(C)C)=CC=CC=C(C)C=CC=C(C)C=CC=C(C)C=CC1=C(C)C[C@@H](O)CC1(C)C</smiles>

(higher price with only satisfactory results).

Encapsulation, in its various forms has also proven to be a solution, although with limited results and difficult to implement in a widespread of foodstuffs. For instance, the disadvantages of adding salt to a foodstuff is widely known, but, they can be overcome by encapsulating the salt, thus controlling its release onto the foodstuff, generally meat. Bioencapsulation, microencapsulation (starch, cellulose, carrageenan, xantham gum, chitosan .... ) and nanoencapsulation (nanocomposites, silicate nanoparticles and nanosilver) have all been used and seem to be promising in terms of what is expected from a food conservation viewpoint. Encapsulation of carotenoids, for instance, can be carried out in many forms, namely through, liposomes, precipitation of nanoparticles, and also through oil/water emulsions, which subdivided into five techniques, such as dead-end membrane emulsification, micro 
channel emulsification, high pressure homogenization, high internal phase emulsions and phase inversion temperature method.

Other solutions, like $\mathrm{pH}$ changes, reduction of water, opaque packaging, among others are all being used to lessen the impact on additives, thus making them needed in a lower quantity to carry out the same effects (Friedman, \& Jürgens, 2000; Handford et al., 2014; Zuidam \& Nedović, 2010). Other techniques involve combining the molecules with other compounds, or into micelles, which has been done with lycopene and other antioxidants. Combinations of polyphenols of cranberry pomace have been combined with proteins in order to stabilize these metabolites (Roopchand et al., 2013; Xu et al., 1999). Synthesis of polyphenols with nanoparticles has been proposed as a stabilizing agent, as well as their linkage with other compounds that further stabilize them (Bilici, Doğan, Yiliorim, \& Kaya, 2013; Siebert, 1999). All these innovations are still pending approval from governing and regulating bodies, but further pressurize them to acknowledge the benefits of answering the consumers demand for more natural food components. Furthermore, new developments will surely bring new techniques, not only for a more efficient extraction with less loss of activity, but also new technologies for stabilization.

\section{New synthetic and natural food additives - conclusions and perspectives}

The food industry, as many other industries, is avid for new technologies, new solutions, new applications, new methodologies, new foods, new products ... Novelty is always accompanied by trends in consumption, and thus, the latest in terms of food and lifestyle is towards healthiness, physical exercise, safe, unprocessed and healthy food. This has been understood by food companies that tend to reduce the load of processing and addition of food additives. Ideally, food would have no conservatives and/or additives, and be unprocessed, but, given hygiene standards, sanity issues, industrial production, distance between production and consumption, profits, demand for certain types of food, the vast majority of food has to undergo some type of processing and some additives added, with the vast majority being added for preservation. The second threshold for food industries is to produce food that is perceived by the consumer as natural, which is related with safety, healthier food, even though sometimes this perception can be erroneous (Siegrist \& Sütterlin, 2017). As stated previously (Carocho \& Ferreira, 2013a,b; Carocho et al., 2015; Carocho et al., 2017), many factors have contributed to this fact, namely studies that are not properly described by the authors, precipitated decisions by governing bodies in terms of banning or allowing additives, ignorance of the public about what is in their food, alarming media headlines, but also food scandals and scares linked to additives that have been ravaging the industry and public opinion. The Pepsi incident of 2015 linked to aspartame, the frequent scandals in China, but also the methyl yellow food scandal of South Korea and many others throughout the world increase distrust and fear in consumers (Carocho et al., 2017; Chemical Watch, 2017; Channel News Asia, 2014).

For instance, in China, the abuse of food additives and use of illegal additives are at the source of most of the food safety incidents, and food diplomatic issues with export of Chinese food to the USA, Japan and South Korea. (Wu, Zhong, Shan, \& Qin, 2013b). Given that most of the scandals are linked to excessive addition of food additives or the use of illegal substances to increase profit, mask problems with the food, consumers generally think that every synthetic compound added to food is potentially harmful, thus preferring natural food which is believed to have a lower probability of having been "tampered" with (Chen, 2017). Mainly due to this distrust, the next generations of food additives, following the trend, will come from natural sources in order to be better accepted by the population for their perception as safer and healthier. New synthetic compounds will also be discovered and new synergies will be established among the known approved additives, which is much easier than the whole hassle of developing a new antioxidant from "scratch". Other approaches to food conservation that could imply a lower load of additives is the dual function additives, in which two types of additives are joined to carry out separate functions within the food, like an antioxidant-sweetener or an antioxidant-colorant. All these advances and hypothetic new additives for foodstuffs are limited by the governing bodies, which are criticized for their delay and conservationism towards new antioxidants or additives, although the EFSA has imposed legal timeframes for approval requests, and has shown a more open position towards new antioxidants, hence the use of rosemary extract as a staple for food conservation. Concomitantly, the probable demystification, efficiency increase and lower price of other types of food conservation techniques will also reduce the need for antioxidants, namely food irradiation, high pressure technology, electroporation, modified atmospheres, nonthermal plasma, biopreservation, or even the combination of more than one of these techniques.

Apart from what the future holds, much works should be put into demystifying food antioxidants and additives in general, reducing consumer stress, fear and distrust, making them believe that not all "E" numbers are hazardous, and that natural and synthetic antioxidants and additives are both classified under the same regulations. But this, is a joint effort that must encompass the industry, the consumers and the governing bodies.

\section{Conflicts of interest}

The authors state no conflicts of interest regarding the manuscript.

\section{Acknowledgments}

The authors are grateful to the Foundation for Science and Technology (FCT, Portugal) and FEDER under Programme PT2020 for financial support to CIMO (UID/AGR/00690/2013). Author Márcio Carocho also thanks FCT for his post-doctoral grant SFRH/BPD/ $114650 / 2016$.

\section{References}

Aguayo, E., Requejo-Jackman, C., Stanley, R., \& Woolf, A. (2010). Effects of calcium ascorbate treatments and storage atmosphere on antioxidant activity and quality of fresh cut apple slices. Postharvest Biology and Technology, 57, 52-60.

Akoh, C. C., \& Min, D. B. (2002). Food lipids: Chemistry, nutrition, and biotechnology. Boca Raton, USA: CRC Press.

Alandes, L., Hernando, I., Quiles, A., Pérez-Munuera, I., \& Lluch, M. A. (2006). Cell wall stability of fresh-cut fuji apples treated with calcium lactate. Journal of Food Science, $71,615-620$.

Alfonso-Prieto, M., Biarnés, X., Vidossich, P., \& Rovira, C. (2009). The molecular mechanism of the catalase reaction. Journal of the American Chemistry Society, 131, $11751-11761$.

Ames, B. N., Shigenaga, M. K., \& Hagen, T. M. (1993). Oxidants, antioxidants, and the degenerative diseases of aging. Proceedings of the National Academy of Sciences of the United States of America, 90, 7915-7922.

Avery, S. V. (2011). Molecular targets of oxidative stress. Biochemical Journal, 434, 201-210.

Ayala, A., Muñoz, M. F., \& Argüelles, S. (2014). Lipid peroxidation: Production, metabolism, and signalling mechanisms of malondialdehyde and 4-hydroxy-2-nonenal. Oxidative Medicine and Cellular Longevity Article ID 360438, 31 pages.

Baines, D., \& Seal, R. (2012). Natural food additives, ingredients and flavorings. Philadelphia: Woodhead Publishing Limited.

Banipal, T. S., Kaur, H., Kaur, A., \& Banipal, P. K. (2016). Effect of tartrate and citrate based food additives in the micellar properties of sodium dodecylsulfate for prospective use as food emulsifier. Food Chemistry, 190, 599-606.

Barba, F. J., Mariutti, L. R. B., Bragagnolo, N., Mercadante, A. Z., Barbosa-Cánovas, G. V., \& Orlien, V. (2017). Bioaccessibility of bioactive compounds from fruits and vegetables after thermal and nonthermal processing. Trends in Food Science \& Technology, 67, 195-206.

Barbosa-Pereira, L., Cruz, J. M., Sendón, R., Quirós, A. R. B., Ares, A., \& Castro-López, M. (2013). Development of an antioxidant active film containing tocopherols to extend the shelf life of fish. Food Control, 31, 236-243.

Battacharyya, A., Chattopadhyay, C., Mitra, S., \& Crowe, S. E. (2014). Oxidative stress: An essential factor in the pathogenesis of gastrointensinal mucosal diseases. Physiology Reviews, 94, 329-354.

Belitz, H. D., Grosch, W., \& Schieberle, P. (2009). Food chemistry (4 ${ }^{\mathrm{a}}$ Ed.). Berlin, Germany: Springer.

Benov, L., \& Beema, A. F. (2003). Superoxide-dependence of the short chain sugars- 
induced mutagenesis. Free Radical Biology \& Medicine, 34, 429-433.

Berardo, A., De Maere, H., Stavropoulou, D. A., Rysman, T., Leroy, F., \& De Smet, S. (2016). Effect of sodium ascorbate and sodium nitrite on protein and lipid oxidation in dry fermented sausages. Meat Science, 121, 359-364.

Bernstein, P. S., Li, B., Vachali, P. P., Gorusupudi, A., Shyam, R., Henriksen, B. S., et al. (2015). Lutein, zeaxanthin, and meso-zeaxanthin: The basic and clinical science underlying carotenoid-based nutritional interventions against ocular disease. Progress in Retinal Eye Research, 50, 34-66.

Bilici, A., Doğan, F., Yildirim, M., \& Kaya, Í. (2013). Facile synthesis of self-stabilized polyphenol nanoparticles. Materials Chemistry and Physics, 140, 66-74.

Birben, E., Sahiner, U. M., Sackesen, C., Erzurum, S., \& Kalayci, O. (2012). Oxidative stress and antioxidant defence. World Allergy Organization Journal, 5, 9-19.

Bradford, D. D., Huffman, D. L., Egbert, W. R., \& Jones, W. R. (1993). Low-fat fresh pork sausage patty stability in refrigerated storage with potassium lactate. Journal of Food Science, 58, 488-491.

Branen, A. L., Davidson, P. M., \& Thorngate, J. H., III (2001). Food additives. New York: Marcel Dekker, Inc.

Brewer, M. S., Mckeith, F., Martin, S. E., Dallmier, A. W., \& Meyer, J. (1991). Sodium lactate effects on shelf-life, sensory, and physical characteristics of fresh pork sausage. Journal of Food Science, 56, 1170-1178.

Carbonell-Capella, J. M., Buniowska, M., Barba, F. J., Esteve, M. J., \& Frígola, A. (2014). Analytical methods for determining bioavailability and bioaccessibility of bioactive compounds from fruits and vegetables: A review. Comprehensive Reviews in Food Science and Food Safety, 13, 155-171.

Carocho, M., Barreiro, M. F., Morales, P., \& Ferreira, I. C. F. R. (2014). Adding molecules to food, pros and cons: A review on synthetic and natural food additives. Comprehensive Reviews in Food Science and Food Safety, 13, 377-399.

Carocho, M., \& Ferreira, I. C. F. R. (2013a). A review on antioxidants, prooxidants and related controversy: Natural and synthetic compounds, screening and analysis methodologies and future perspectives. Food and Chemical Toxicology, 51, 15-25.

Carocho, M., \& Ferreira, I. C. F. R. (2013b). The role of phenolic compounds in the fight against cancer - a review. Anti-cancer Agents in Medicinal Chemistry, 13, 1236-1258.

Carocho, M., Morales, P., \& Ferreira, I. C. F. R. (2015). Natural food additives: Quo vadis? Trends in Food Science and Technology, 45, 284-295.

Carocho, M., Morales, P., \& Ferreira, I. C. F. R. (2017). Sweeteners as food additives in the XXI century: A review of what is known, and what is to come. Food and Chemical Toxicology, 107, 302-317.

Chammem, N., Saoudi, S., Sifaoui, I., Sifi, S., Person, M., Abderraba, M., et al. (2015). Improvement of vegetable oils quality in frying conditions by adding rosemary extract. Industrial Crops and Products, 74, 592-599.

Channel News Asia (2014). Taiwan recalls tainted dried tofu in fresh food scare. Available at: https://web.archive.org/web/20141219111820/http://www.channelnewsasia. $\mathrm{com} /$ news/asiapacific/taiwan-recalls-tainted/1535406.html.

Chemical Watch (2017). Taiwan tackles risky chemical in food. Available at: https:// chemicalwatch.com/57369/taiwan-tackles-risky-chemicals-in-food.

Chen, M. (2017). Modelling an extended theory of planned behaviour model to predict intention to take precautions to avoid consuming food with additives. Food Quality and Preference, 58, 24-33.

Chen, H. C., Gonzalez, F. J., Shou, M., \& Chung, F. (1998). 2,3-epoxy-4-hydroxynonanal, a potential lipid peroxidation product for etheno adduct formation, is not a substrate of human epoxide hydrolase. Carcinogenesis, 19, 939-943.

Choe, E., \& Min, D. B. (2009). Mechanisms of antioxidants in the oxidation of foods. Comprehensive Reviews in Food Science and Food Safety, 8, 345-358.

Commission Regulation (2011). Commission regulation (EU) No. 1129/2011 of 11 november 2011 amending annexx II to regulation (EC) No. 1333/2008 of the European parliament and of the council by establishing a union list of food additives text with EEA relevance. Available at: http://eur-lex.europa.eu/legal-content/EN/ALL/?uri= CELEX\%3A32011R1129.

Commission Report, REPORT FROM THE COMMISSION on Dietary Food Additive Intake in the European Union (http://ec.europa.eu/food/fs/sfp/addit_flavor/flav15_en.pdf).

Crist, C. A., Williams, J. B., Hood, A. F., Smith, B. S., \& Campano, S. G. (2014). Impact of sodium lactate and vinegar derivatives on the quality of fresh Italian pork sausage links. Meat Science, 96, 1509-1516.

Cruzen, S. M., Kim, Y. H. B., Lonergan, S. M., Grubbs, J. K., Fritchen, A. N., \& HuffLonergan, E. (2015). Effect of early post-mortem enhancement of calcium lactate/ phosphate on quality attributes of beef round muscles under different packaging systems. Meat Science, 101, 63-72.

Deans, R. T., Fu, S., Stocker, R., \& Davies, M. J. (1997). Biochemistry and pathology of radical-mediated protein oxidation. Biochemistry Journal, 324, 1-18.

Decker, E. A., Elias, R. J., \& McClements, D. J. (2010). Oxidation in foods and beverages and antioxidant applications. Philadelphia: Woodhead Publishing Limited.

De'Nobili, M. D., Soria, M., Martinefski, M. R., Tripodi, V. P., Fissore, E. N., \& Rojas, A. M. (2016). Stability of L- (+)-ascorbic acid in alginate edible films loaded with citric acid for antioxidant food preservation. Journal of Food Engineering, 175, 1-7.

EFSA (2008). Statement of the scientific panel of food additives, flavourings, processing aids and materials in contact with food on a request from the European Commission concerning the use of lactic acid and sodium lactate and sodium lactate for poultry carcass decontamination. EFSA Journal, 6, 234-235.

EFSA (2011). Scientific opinion on the re-evaluation of butylated hydroxyanisole - BHA (E320) as a food additive. EFSA Journal, 9, 2392-2441.

EFSA (2012). Scientific opinion on the re-evaluation of butylated hydroxytoluene BHT (E 321 ) as a food additive. EFSA Journal, 10, 2588-2631.

EFSA (2014a). Scientific opinion on the re-evaluation of propyl gallate (E310) as a food additive. EFSA Journal, 12, 3642-3688.

EFSA (2014b). Scientific opinion on the re-evaluation of propyl gallate (E 310) as a food additive EFSA Journal, 12, 3642.
EFSA (2015a). Scientific opinion on the re-evaluation of ascorbic acid (E 300), sodium ascorbate (E 301) and calcium ascorbate (E 302) as food additives. EFSA Journal, 13, 4087-4211.

EFSA (2015b). Scientific opinion on the re-evaluation of ascorbyl palmitate (E304(i)) and ascorbyl stearate (E304(ii)) as food additives. EFSA Journal, 13, 4289-4346.

EFSA (2015c). Scientific opinion on the re-evaluation of tocopherol-rich extract (E306), $\alpha$-tocopherol (E307), $\gamma$-tocopherol (E308) and $\delta$-tocopherol (E309) as food additives. EFSA Journal, 13, 4247-4365.

EFSA (2015d). Scientific opinion on the re-evaluation of octyl gallate (E311) as a food additive. EFSA Journal, 13, 4248-4287.

EFSA (2015e). Scientific opinion on the re-evaluation of dodecyl gallate (E312) as a food additive. EFSA Journal, 13, 4086-4125.

EFSA (2015f). Extension of use of extracts of rosemary E392) in fat-based spreads. EFSA Journal, 13, 4090-4112.

EFSA (2016a). Scientific opinion on the re-evaluation of erythorbic acid (E315) and sodium erythorbate (E316) as food additives. EFSA Journal, 14, 4360-4411.

EFSA (2016b). Statement on the refined exposure assessment of tertiary-butyl hydroquinone (E31). EFSA Journal, 14, 4363-4389.

Ferreira, I. C. F. R., Barros, L., \& Abreu, R. M. V. (2009). Antioxidants in wild mushrooms. Current Medicinal Chemistry, 16, 1543-1560.

Fidler, M. C., Davidsson, L., Zede, C., \& Hurrell, R. F. (2004). Erythrobic acid is a potent enhancer of nonheme-iron absorption. American Journal of Clinical Nutrition, 79, 99-102.

Figueirêdo, B. C., Trad, I. J., Mariutti, L. R. B., \& Bragagnolo, N. (2014). Effect of annatto powder and sodium erythorbate on lipid oxidation in pork loin during frozen storage. Food Research International B, 65, 137-143.

Fridovich, I. (1983). Superoxide radical: An endogenous toxicant. Annual Reviews in Toxicology, 23, 239-257.

Friedman, M., \& Jürgens, H. S. (2000). Effect of pH on the stability of plant phenolic compounds. Journal of Agricultural and Food Chemistry, 48, 2101-2110.

Fujita, K., \& Kubo, I. (2002). Antifungal activity of octyl gallate. International Food Microbiology, 79, 193-201.

Gálico, D. A., Nova, C. V., Guerra, R. B., \& Bannach, G. (2015). Thermal and spectroscopic studies on the antioxidant food additive propyl gallate. Food Chemistry, 182, 89-94.

Gao, M., Feng, L., Jiang, T., Zhu, J., Fu, L., Yuan, D., et al. (2014). The use of rosemary extract in combination with nisin to extend the shelf life of pompano (Trachinotus ovatus) filler during chilled storage. Food Control, 37, 1-8.

Gharavi, N., \& El-Kadi, A. O. S. (2005). tert-butylhydroquinone is a novel aryl hydrocarbon receptor ligand. Drug Metabolism and Disposition, 33, 365-372.

Gimeno, O., Astiasarán, I., \& Bello, J. (2001). Calcium ascorbate as a potential partial substitute for $\mathrm{NaCl}$ in dry fermented sausages: Effect on colour, texture, and hygienic quality at different concentrations. Meat Science, 57, 23-29.

Granato, D., Nunes, D. S., \& Barba, F. J. (2017). Na integrated strategy between food chemistry, biology, nutrition, pharmacology, and statistics in the development of functional foods: A proposal. Trends in Food Science and Technology, 62, 13-22.

Gruhlke, M. C. H., \& Slusarenko, A. J. (2012). The biology of reactive sulfur species (RSS). Plant Physiology and Biochemistry, 59, 98-107.

Guo, Q., Gao, S., Sun, Y., Gao, W., \& Zhang, Z. (2016). Antioxidant efficacy of rosemary ethanol extract in palm oil during frying and accelerated storage. Industrial Crops and Products, 94, 82-88.

Haila, K. M., Lievonen, S. M., \& Heinonen, M. I. (1996). Effects of lutein, lycopene, annatto, and $\gamma$-tocopherol on autoxidation of triglycerides. Journal of Agricultural and Food Chemistry, 44, 2096-2100.

Halliwell, B. (1990). How to characterize a biological antioxidant. Free Radical Research Communications, 9, 1-32.

Handford, C. E., Dean, M., Henchion, M., Spence, M., Elliott, C. T., \& Campbell, K. (2014) Implication of nanotechnology for the agri-food industry: Opportunities, benefits and risks. Trends in Food Science \& Technology, 40, 226-241.

Heijden, C. A., Janssen, P. J. C. M., \& Strik, J. J. T. W. A. (1986). Toxicology of gallates: A review and evaluation. Food and Chemical Toxicology, 24, 1067-1070.

Hernández-Muñoz, P., Almenar, E., Ocio, M. J., \& Gavara, R. (2006). Effect of calcium dips and chitosan coatings on postharvest life of strawberries (Fragraria $\mathrm{x}$ ananassa). Postharvest Biology and Technology, 39, 247-253.

Hsu, F., Chang, H., \& Chang, S. (2007). Evaluation of antifungal properties of octyl gallate and its synergy with cinnamaldehyde. Bioresource Technology, 98, 734-738.

Hsu, S. Y., \& Sun, L. (2006). Effects of salt, phosphates, potassium sorbate ad sodium erythorbate on qualities of emulsified meatball. Journal of Food Engineering, 73, $246-252$.

Hui, Y. H. (2006). (1st ed.). Handbook of food science, technology, and engineeringVol. 1. Boca Raton, Florida, USA: CRC Press, Taylor \& Francis.

Igoe, R. S. (2011). Dictionary of food ingredients ( $5^{\text {th }}$ ed.). New York, USA: Springer, Science + Business Media.

Ilhak, O. I., \& Guran, H. S. (2014). Combined antimicrobial effect of thymol and sodium lactate against Listeria monocytogenes and Salmonella typhimurium in fish patty. Journal of Food Safety, 34, 211-271.

Jacobi, H., Eicke, B., \& Witte, I. (1998). DNA strand break induction and enhanced cytotoxicity of propyl gallate in the presence of copper (II). Free Radical Biology and Medicine, 24, 972-978.

JECFA (2006a). Joint FAO/WHO Expert committee on food additives. Potassium lactate, monograph 1. Available at: http://www.fao.org/food/food-safety-quality/scientificadvice/jecfa/jecfa-additives/details-simple/en/?ins_id $=326$.

JECFA (2006b). Joint FAO/WHO Expert committee on food additives. Calcium lactate, monograph 1. Available at: http://www.fao.org/food/food-safety-quality/scientificadvice/jecfa/jecfa-additives/details-simple/en/?ins_id $=327$.

JECFA (2006c). Joint FAO/WHO Expert committee on food additives. Trisodium citrate, monograph 1. Available at: http://www.fao.org/food/food-safety-quality/scientific- 
advice/jecfa/jecfa-additives/details-simple/en/?ins_id = 331(iii)

JECFA (2006d). Joint FAO/WHO Expert committee on food additives. Potassium dihydrogen citrate, monograph 1. Available at: http://www.fao.org/food/food-safety-quality/ scientific-advice/jecfa/jecfa-additives/details-simple/en/?ins_id =332(i).

JECFA (2006f). Joint FAO/WHO Expert committee on food additives. $L(+)$-tartaric acid, monograph 1. Available at: http://www.fao.org/food/food-safety-quality/scientific advice/jecfa/jecfa-additives/details-simple/en/?ins_id $=334$.

JECFA (2006g). Joint FAO/WHO Expert committee on food additives. Potassium sodium $L$ (+)- tartrate, monograph 1. Available at: http://www.fao.org/food/food-safetyquality/scientific-advice/jecfa/jecfa-additives/details-simple/en/?ins_id $=337$.

JECFA (2006h). Joint FAO/WHO expert committee on food additives. Phosphoric acid, Monograph 1. Available at: http://www.fao.org/food/food-safety-quality/scientific advice/jecfa/jecfa-additives/details-simple/en/?ins id $=338$.

JECFA (2006i). Joint FAO/WHO Expert committee on food additives. Disodium hydrogen phosphate, monograph 1. Available at: http://www.fao.org/food/food-safety-quality/ scientific-advice/jecfa/jecfa-additives/details-simple/en/?ins id =339(ii).

JECFA (2006j). Joint FAO/WHO Expert committee on food additives. Sodium dihydrogen phosphate, monograph 1. Available at: http://www.fao.org/food/food-safety-quality/ scientific-advice/jecfa/jecfa-additives/details-simple/en/?ins_id=339(i).

JECFA (2007). Joint FAO/WHO Expert committee on food additives. Calcium citrate, monograph 4. Available at: http://www.fao.org/food/food-safety-quality/scientificadvice/jecfa/jecfa-additives/details-simple/en/?ins_id = 333(iii)

JECFA (2009). Joint FAO/WHO Expert committee on food additives. Sodium L(+)-tartrate, monograph 7. Available at: http://www.fao.org/food/food-safety-quality/scientificadvice/jecfa/jecfa-additives/details-simple/en/?ins_id=335(ii).

JECFA (2014). Joint FAO/WHO Expert committee on food additives. Citric acid, monograph 16. Available at: http://www.fao.org/food/food-safety-quality/scientific-advice/ jecfa/jecfa-additives/details-simple/en/?ins_id $=330$.

JEFCA (2006e). Joint FAO/WHO Expert committee on food additives. Triammonium citrate, monograph 1. Available at: http://www.fao.org/food/food-safety-quality/scientificadvice/jecfa/jecfa-additives/details-simple/en/?ins_id $=380$.

JEFCA (2006k). Joint FAO/WHO Expert committee on food additives. Trisodium phosphate, monograph 1. Available at: http://www.fao.org/food/food-safety-quality/scientific advice/jecfa/jecfa-additives/details-simple/en/?ins id = 339(iii)

JEFCA (20061). Joint FAO/WHO Expert committee on food additives. Dipotassium hydrogen phosphate, monograph 1. Available at: http://www.fao.org/food/food-safety-quality/ scientific-advice/jecfa/jecfa-additives/details-simple/en/?ins id = 340(ii).

JEFCA (2006m). Joint FAO/WHO Expert committee on food additives. Potassium dihydrogen phosphate, monograph 1. Available at: http://www.fao.org/food/food-safety-quality/ scientific-advice/jecfa/jecfa-additives/details-simple/en/?ins_id=340(i).

JEFCA (2006n). Joint FAO/WHO Expert committee on food additives. Tripotassium phosphate, monograph 1. Available at: http://www.fao.org/food/food-safety-quality/ scientific-advice/jecfa/jecfa-additives/details-simple/en/?ins_id =340(iii).

JEFCA (2006o). Joint FAO/WHO Expert committee on food additives. Calcium dihydrogen phosphate, monograph 1. Available at: http://www.fao.org/food/food-safety-quality/ scientific-advice/jecfa/jecfa-additives/details-simple/en/?ins_id =341(i).

JEFCA (2006p). Joint FAO/WHO Expert committee on food additives. Calcium hydrogen phosphate, monograph 1. Available at: http://www.fao.org/food/food-safety-quality/ scientific-advice/jecfa/jecfa-additives/details-simple/en/?ins_id = 341(ii).

JEFCA (2006q). Joint FAO/WHO Expert committee on food additives. Tricalcium phosphate Available at: http://www.fao.org/food/food-safety-quality/scientific-advice/jecfa/ jecfa-additives/details-simple/en/?ins_id $=341$ (iii).

JEFCA (2006r). Joint FAO/WHO Expert committee on food additives. Magnesium hydrogen phosphate, monograph 1. Available at: http://www.fao.org/food/food-safety-quality/ scientific-advice/jecfa/jecfa-additives/details-simple/en/?ins id=343(ii).

JEFCA (2006s). Joint FAO/WHO Expert committee on food additives. Trimagnesium phosphate, monograph 1. Available at: http://www.fao.org/food/food-safety-quality/ scientific-advice/jecfa/jecfa-additives/details-simple/en/?ins id = 343(iii).

JEFCA (2006t). Joint FAO/WHO Expert committee on food additives. Sodium DL-malate, monograph 3. Available at: http://www.fao.org/food/food-safety-quality/scientific advice/jecfa/jecfa-additives/details-simple/en/?ins_id = 350(ii).

JEFCA (2006u). Joint FAO/WHO Expert committee on food additives. Sodium hydrogen DLmalate, monograph 3. Available at: http://www.fao.org/food/food-safety-quality/ scientific-advice/jecfa/jecfa-additives/details-simple/en/?ins_id = 350(i).

JEFCA (2006v). Joint FAO/WHO Expert committee on food additives. Calcium DL-malate, monograph 3. Available at: http://www.fao.org/food/food-safety-quality/scientificadvice/jecfa/jecfa-additives/details-simple/en/?ins_id = 352(ii).

JEFCA (2008). Joint FAO/WHO Expert committee on food additives. Magnesium dihydrogen phosphate, monograph 5. Available at: http://www.fao.org/food/food-safety-quality/ scientific-advice/jecfa/jecfa-additives/details-simple/en/?ins_id=343(i).

Jongberg, S., Tørngren, M. A., Gunvig, A., Skibsted, L. H., \& Lund, M. N. (2013). Effect of green tea or rosemary extract on protein oxidation in Bologna type sausages prepared from oxidatively stressed pork. Meat Science, Vol. 93, 538-546.

Kamil, A., Smith, D. E., Blumberg, J. B., Astete, C., Sabilov, C., \& Chen, C. Y. O. (2016). Bioavailability and biodistribution of nanodelivered lutein. Food Chemistry, 192, 915-923.

Kayama, Y., Raaz, U., Jagger, A., Adam, M., Schellinger, I. N., Sakamoto, M., et al. (2015). Diabetic cardiovascular disease induced by oxidative stress. International Journal of Molecular Science, 16, 25234-25263.

Kerry, J. P., \& Kerry, J. F. (2011). Processed meats: Improving safety, nutrition and quality ( $1^{\text {st }}$ ed.). Cambridge, UK: Woodhead Publishing Limited.

Kim, Y. H. B., Huff-Lonergan, E., \& Lonergan, S. M. (2012). Effect of calcium lactate on mcalpain activity and protein degradation under oxidising conditions. Food Chemistry, 131, 73-78.

Kim, Y. H., Keeton, J. T., Yang, H. S., Smith, S. B., Sawyer, J. E., \& Savell, J. W. (2009b). Color stability and biochemical characteristics of bovine muscles when enhanced with L- or D-potassium lactate in high-oxygen modified atmospheres. Meat Science, $82,234-240$.

Kim, Y. H., Keeton, J. T., Smith, S. B., Maxim, J. E., Yang, H. S., \& Savell, J. W. (2009a). Evaluation of antioxidant capacity and colour stability of calcium lactate enhancement on fresh beef under highly oxidising conditions. Food Chemistry, 115, 272-278.

Kiokias, S., \& Gordon, M. H. (2003). Antioxidant properties of annatto carotenoids. Food Chemistry, 83, 523-529.

Končić, M. Z., Barbarić, M., Perković, I., \& Zorc, B. (2011). Antiradical, chelating and antioxidant activities of hydroxamic acids and hydroxyureas. Molecules, 16, 6232-6242.

Kubo, I., Fujita, K., Nihei, K., \& Masuoka, N. (2003). Non-antibiotic Antibacterial activity of dodecyl gallate. Bioorganic Medicinal Chemistry, 11, 573-580.

Kubo, I., Masuoka, N., Xiao, P., \& Haraguchi, H. (2002). Antioxidant activity of dodecyl gallate. Journal of Agricultural and Food Chemistry, 50, 3533-3539.

Kubo, I., Muroi, H., \& Kubo, A. (1993). Antibacterial activity of long-chain alcohols against Streptococcus mutans. Journal of Agricultural and Food Chemistry, 41, 2447-2450.

Kubo, I., Xiao, P., \& Fujita, K. (2001). Antifungal activity of octyl gallate: Structural criteria and mode of action. Bioorganic Medicinal Chemistry Letters, 11, 347-350.

Lakshminarayana, R., Aruna, G., Sthisha, U. V., Dharmesh, S. M., \& Baskaran, V. (2013). Structural elucidation of possible lutein oxidation products mediated through peroxyl radical inducer 2,2'-Azobis (2-methylpropionamidine) dihydrochloride: Antioxidant and cytotoxic influence of oxidized lutein in HeLa cells. Chemico-biology Interactions, 203, 448-455.

Lakshminarayana, R., Sathish, U. V., Dharesh, S. M., \& Baskaran, V. (2010). Antioxidant and cytotoxic effect of oxidized lutein in human cervical carcinoma cells (HeLa). Food and Chemical Toxicology, 48, 1811-1816.

Lin, S., \& Pascall, M. A. (2014). Incorporation of vitamin E into chitosan and its effect on the film forming solution (viscosity and drying rate) and the solubility and thermal properties of the dried film. Food Hydrocolloids, 35, 78-84.

Liu, Z. (2006). Kinetic study on the prooxidative effect of vitamin C on the autoxidation of glycerol trioleate in micelles. Journal of Physical Organic Chemistry, 136-142.

Liu, K., Liu, J., Yuan, C., Zhong, J., \& Chen, Y. (2016). Influence of postharvest citric acid and chitosan coating treatment on ripening attributes and expression of cell wall related genes in cherimoya (Annona cherimola Mill.) fruit. Scientia Horticulturae, 198, $1-11$.

Lobo, V., Phatak, A., \& Chandra, N. (2010). Free radicals and functional foods: Impact on human health. Pharmacognosy Reviews, 4, 112-126.

Lü, J., Lin, P. H., Yao, Q., \& Chen, C. (2010). Chemical and molecular mechanisms of antioxidants: Experimental approaches and model systems. Journal of Cellular and Molecular Medicine, 14, 840-860.

Luna-Guzmán, I., \& Barrett, D. M. (2000). Comparison of calcium chloride and calcium lactate effectiveness in maintaining shelf stability and quality of fresh-cut cantaloupes. Postharvest Biology and Technology, 19, 61-72.

Maca, J. V., Miller, R. K., \& Acuf, G. R. (1997). Microbiological, sensory and chemica characteristics of vacuum-packed ground beef patties treated with salts of organic acids. Journal of Food Science, 62, 591-596.

Maesk, A., Chrzescijanska, E., Zaborski, M., \& Piotrowska, M. (2014). Dodecyl gallate as a pro-ecological antioxidant for Food packing materials. Comptes Rendus Chimie, 17, $1116-1127$.

Manganaris, G. A., Vasilakakis, M., Diamantidis, G., \& Mignani, I. (2005). Effect of calcium additives on physicochemical aspects of cell wall pectin and sensory attributes of canned peach (Prunus persica (L) Batsch cv Andross). Journal of Science of Food and Agriculture, 85, 1773-1778.

Ma, Y., Pan, J., Zhang, G., \& Zhang, Y. (2013). Binding properties of butylated hydroxytoluene with calf thymus DNA in vitro. Journal of Phytochemistry and Photobiology B: Biology, 126, 112-118.

Marcos, B., Sarraga, C., Castellari, M., Kappen, F., Schennik, G., \& Arnau, J. (2014). Development of biodegradable films with antioxidant properties based on polyesters containing $\alpha$-tocopherol and olive leaf extract for food packaging applications. Food Packaging and Shelf-life, 1, 140-150.

Martínez-Delgado, A. A., Khandual, S., \& Villanueva-Rodríguez, S. J. (2017). Chemical stability of astaxanthin integrated into a Food matrix: Effects of Food processing and methods for preservation. Food Chemistry, 225, 23-30.

Masuda, T., Shimazawa, M., \& Hara, H. (2017). Retinal diseases associated with oxidative stress and the effects of a free radical scavenger (Edaravone). Oxidative Medicine and Cellular Longevity Article ID 9208489, 14 pages.

Mirończuk-Chodakowska, I., Witkowska, A. M., \& Zujko, M. E. (2018). Endogenous nonenzymatic antioxidants in the human body. Advances in Medicinal Sciences, 63, 68-78.

Mitri, K., Shegokar, R., Hohla, S., Anselmi, C., \& Müller, R. H. (2011). Lutein nanocrystals as antioxidant formulation for oral and dermal delivery. International Journal of Pharmacy, 420, 141-146.

Miura, K., Yazama, F., \& Tai, A. (2015). Oxidative stress-mediated antitumor activity of erythorbic acid in high doses. Biochemical and Biophysical Reports, 3, 117-122.

Moncada, S., \& Higgs, A. (1993). The L-arginine-nitric oxide pathway. New England Journal of Medicine, 329, 2002-2012.

Msagati, T. A. M. (2013). Chemistry of food additives and preservatives ( $1^{\text {st }}$ ed.). West Sussex, UK: John Wiley and Sons.

Naidu, A. S. (2000). Natural Food antimicrobial systems ( $2^{\text {nd }}$ ed.). Boca Raton, Florida, EUA: CRC Press.

Nnanna, I. A., Ukuku, D. O., McVann, K. B., \& Shelef, L. A. (1994). Antioxidant activity of sodium lactate in meat and model systems. LWT-Food Science and Technology, 27, $78-85$.

Noguchi, N., Yamashita, H., Hamahara, J., Nakamura, A., Kühn, H., \& Niki, E. (2002). The specificity of lipoxygenase-catalyzed lipid peroxidation and the effects of radicalscavenging antioxidants. Biological Chemistry, 619-626. 
Nykänen, A., Weckman, K., \& Lapveteläinen, A. (2000). Synergistic inhibition of Listeria monocytogenes on cold-smoked rainbow trout by nisin and sodium lactate. International Journal of Food Microbiology, 61, 63-72.

Olson, J. B., Ward, N. E., \& Koutsos, E. A. (2008). Lycopene incorporation into egg yolk and effects on laying hen immune function. Poultry Science, 87, 2573-2580.

Pacher, P., Beckman, J. S., \& Liaudet, L. (2007). Nitric oxide and peroxynitrite in health and disease. Physiology Reviews, 87, 315-424.

Papadopoulos, L. S., Miller, R. K., Acuff, G. R., Vanderzant, C., \& Cross, H. R. (1991). Effect of sodium lactate on microbial and chemical composition of cooked beef during storage. Journal of Food Science, 56, 341-347.

Pisoschi, A. M., \& Pop, A. (2015). The role of antioxidants in the chemistry of oxidative stress: A review. European Journal of Medicinal Chemistry, 97, 55-74.

Rahman, K. (2007). Studies on free radicals, antioxidants, and co-factors. Clinical Interventions in Aging, 2, 219-236.

Rahman, T., Hosen, I., Islam, M. M. T., \& Shekhar, H. U. (2012). Oxidative stress and human health. Advances in Bioscience and Biotechnology, 3, 997-1019.

Ritz, E., Hahn, K., Ketteler, M., Kuhlmann, M. K., \& Mann, J. (2012). Phosphate additives in food - a health risk. Deutsches Ärzteblatt International, 109, 49-55.

Roopchand, D. E., Krueger, C. G., Moskal, K., Fridlender, B., Lila, M. A., \& Raskin, I. (2013). Food-compatible method for the efficient extraction and stabilization of cranberry pomace polyphenols. Food Chemistry, 141, 3664-3669.

Roushani, M., \& Sarabaegi, M. (2014). Electrochemical detection of butylated hydroxyanisole based on glassy carbon electrode modified iridium oxide nanoparticles. Journal of Electroanalytical Chemistry, 717, 147-152.

Sallam, K. I. (2007). Antimicrobial and antioxidant effects of sodium acetate, sodium lactate, and sodium citrate in refrigerated sliced salmon. Food Control, 18, 566-575.

Sallam, K. I., \& Samejima, K. (2004). Microbiological and chemical quality of ground beef treated with sodium lactate and sodium chloride during refrigerated storage. Lebenson Wiss Technology, 37, 865-871.

Schelegueda, L. I., Gliemmo, M. F., \& Campos, C. A. (2012). Antimicrobial synergic effect of chitosan with sodium lactate, nisin or potassium sorbate against the bacterial flora of fish. Journal of Food Research, 1, 272-281.

Seppanen, C. M., Song, Q., \& Csallany, A. S. (2010). The antioxidant functions of tocopherol and tocotrienol homologues in oils, fats, and food systems. Journal of the American Oil Chemists Society, 87, 469-481.

Shah, A. M., \& Channon, K. M. (2004). Free radicals and redox signalling in cardiovascular disease. Heart, 90, 486-487.

Shahidi, F. (2015). Handbook of antioxidants and food preservation. Cambridge: Woodhead Publishing Limited.

Shin, D. S., DiDonato, M., Barondeau, D. P., Hura, G. L., Hitomi, C., Berglund, J. A., et al. (2009). Superoxide dismutase structures, stability, mechanism and insights into the human disease Amyotrophic Lateral Sclerosis from Eukaryotic thermophile Alvinella pompejana. Journal of Molecular Biology, 385, 1534-1555.

Siebert, K. J. (1999). Effects of protein-polyphenol interactions on beverage haze, stabilization, and analysis. Journal of Agricultural and Food Chemistry, 47, 353-362.

Siegrist, M., \& Sütterlin, B. (2017). Importance of perceived naturalness for acceptance of food additives and cultured meat. Appetite, 113, 320-326.

Smith, J., \& Hong-Shum, L. (2003). Food additives data book. Oxford: Blackwell Science Ltd.

Sofos, J. N., \& Busta, F. F. (1980). Alternatives to the use of nitrite as na antibotulinal agent. Food Technology, (May), 244-251.

Stekelenburg, F. K., \& Kant-Muermans, M. L. T. (2001). Effect of sodium lactate and other additives in a cooked ham product on sensory quality and development of a strain of Lactobacillus curvatus and Listeria monocytogenes. International Journal of Food
Microbiology, 66, 197-203.

Upadhyay, R., \& Mishra, H. N. (2014). Antioxidant activity measurement of oleoresin from Rosemary and sage. Industrial Crops and Products, 453-459.

Uttara, B., Singh, A. V., Zamboni, P., \& Mahajan, R. T. (2009). Oxidative stress and neurodegenerative diseases: A review of upstream and downstream antioxidant therapeutic options. Current Neuropharmacology, 7, 65-74.

Valko, M., Izakovic, M., Mazur, M., Rhodes, C. J., \& Telser, J. (2004). Role of oxygen radicals in DNA damage and cancer incidence. Molecular Cell Biochemistry, 266, 37-56.

Valko, M., Rhodes, C. J., Moncol, J., Izakovic, M., \& Mazur, M. (2006). Free radicals, metals and antioxidants in oxidative stress-induced cancer. Chemico-biological Interactions, 160, 1-40.

Vickers, P. J., Braybrook, J., Lawrence, P., \& Gray, K. (2007). Detecting tartrate additives in foods: Evaluating the use of capillary electrophoresis. Journal of Food Composition and Analysis, 20, 252-256.

Wang, H., Feng, H., \& Luo, Y. (2007). Control of browning and microbial growth on freshcut apples by sequential treatment of sanitizers and calcium ascorbate. Journal of Food Science, 72, 1-7.

Wang, Y., Li, F., Zhuang, H., Chen, X., Li, L., Qiao, W., et al. (2015). Effects of plant polyphenols and $\alpha$-tocopherol on lipid oxidation, residual nitrites, biogenic amines, and N-nitrosamines formation during ripening and storage of dry-cured bacon. LWTFood Science and Technology, 60, 199-206.

Weaver, R. A., \& Shelef, L. A. (1993). Antilisterial activity of sodium, potassium, or calcium lactate in pork liver sausage. Journal of Food Safety, 13, 133-146.

Wit, J. C., \& Rombouts, F. M. (1990). Antimicrobial activity of sodium lactate. Food Microbiology, 7, 113-120.

Wu, J. Q., Kosten, T. R., \& Zhang, X. Y. (2013a). Free radicals, antioxidant defence systems, and schizophrenia. Progress in Neuro-psychopharmacology and Biological Psychiatry, 46, 200-206.

Wu, L., Zhong, Y., Shan, L., \& Qin, W. (2013b). Public risk perception of food additives and food scares. The case of Suzhou, China. Appetite, 70, 90-98.

Xu, X., Wang, Y., Constantinou, A. I., Stacewicz-Sapuntzakis, Bowen, P. E., \& van Breemen, R. B. (1999). Solubilization and stabilization of carotenoids using micelles: Delivery of lycopene to cells in culture. Lipids, 34, 1031-1036.

Yang, J., Guo, J., \& Yuan, J. (2008). In vitro antioxidant properties of rutin. LWT-Food Science and Technology, 41, 1060-1066.

Yang, Y., Song, X., Sui, X., Qi, B., Wang, Z., Li, Y., et al. (2016). Rosemary extract can be used as a synthetic antioxidant to improve vegetable oil oxidative stability. Industrial Crops and Products, 80, 141-147.

Yavari, A., Javardi, M., Mirmiran, P., \& Bahadoran, Z. (2015). Exercise-induced oxidative stress and dietary antioxidants. Asian Journal of Sports Medicine, 6, e24898.

Zavodnik, I. B., Lapshina, E. A., Zavodnik, L. B., Soszyński, M., \& Bryszewska, M. (2002). Hypochlorus acid-induced oxidative damage of human red blood cells: Effects of tertbutyl hydroperoxide and nitrite on the $\mathrm{HOCl}$ reaction with erythrocytes. Bioelectrochemistry, 58, 127-135.

Zeikus, J. G., Jain, M. K., \& Elankovan, P. (1999). Biotechnology of succinic acid production and markets for derived industrial products. Applied Microbiology and Biotechnology, 51, 545-552.

Zuidam, N. J., \& Nedović, V. A. (2010). Encapsulation technologies for active Food ingredients and food processing ( $1^{\text {st }}$ ed.). Springer Science + Business Media, LLC.

Zurita, J. L., Jose, Á., Peso, A., Salguero, M., López-Artíguez, M., \& Repetto, G. (2007). Ecotoxicological effects of the antioxidant additive propyl gallate in five aquatic systems. Water Research, 41, 2599-2611. 